\title{
O CONCEITO CIENTÍFICO DE PROCESSO ADMINISTRATIVO
}

\author{
Ricardo Marcondes MartiNS*
}

1. Introdução - 2. O Processo - 2.1. Teorias sobre a natureza jurídica do processo civil - 2.2. A teoria da relação jurídica de Oskal von Bülow. A teoria da situação jurídica de James Goldschmidt - 2.3. O processo como procedimento - 2.4. Processo como procedimento contraditório -2.5 . A nova formulação da teoria da relação jurídica processual - 2.6. Processo e Procedimento: diferenciação - 3. O Processo Administrativo - 3.1. Breve introdução - 3.2. O procedimento administrativo na teoria dos atos administrativos - 3.3. O procedimento administrativo e o exercício da função administrativa -3.4 . $\mathrm{O}$ uso da expressão procedimento administrativo - 3.5. O uso da expressão processo administrativo - 3.6. Os conceitos científicos de processo e procedimento administrativos - 3.7. A dupla finalidade do processo administrativo - 3.8. As espécies de processos administrativos - 3.8.1. Processos administrativos de defesa - 3.8.2. Processos administrativos de participação - 3.9. Procedimentos administrativos autônomos - 3.10. A competência legislativa - 4. Princípios Regentes Do Processo Administrativo - 4.1. Breve introdução - 4.2. Os sistemas administrativos - 4.3 Os institutos fundamentais do Direito Processual (jurisdicional) e seus correspondentes no Direito Processual Administrativo - 4.4. Processo jurisdicional e administrativo: diferenças fundamentais - 4.5. O Devido Processo Legal: conceito - 4.6. O devido processo legal e o processo administrativo -5 . Conclusões Referências Bibliográficas

* O autor é Procurador do Município de São Paulo e mestrando em Dircito Administrativo da PUC-SP. 


\section{Introduçũo}

Pouco se escreveu sobre processo administrativo no Brasil. Só após 1988. com a vigente Constituição da República, por força, principalmente, da menção expressa no inciso $\mathrm{LV}$ do art. $5^{\circ}$, o instituto recebeu maior atenção. Prova disso é a recentidade das leis que o disciplinam: a Lei paulista (10.177) data de 30 de dezembro de 1998: a Lei federal (9.784), de 29 de janeiro de 1999. O texto impulsionou ainda uma incipiente produção doutrinária. Quase todas as monografias brasileiras sobre o assunto, das poucas existentes, surgiram após a promulgação do último texto constitucional. ${ }^{\text {? }}$

Ao contrário da reduzida produção doutrinária, fértil é a contribuição jurisprudencial sobre o assunto. ${ }^{2}$ A colaboração jurisprudencial, no entanto, sempre limitada ac caso concreto, deixa de lado considerações conceituais. O conhecimento pragmático dela decorrente carece da análise ontológica. Seu desiderato é a práxis e não o desenvolvimento científico.

É, de fato, à doutrina a quem cabe tecer considerações dessa ordem. Superar os "lugares comuns", os conceitos arraigados na tradição e reiteradamente repetidos pelos doutos, debruçar-se sobre o instituto e fixar seus limites conceituais, explicitar sua essência, revelar, enfim. os contornos do processo administrativo.

As primeiras linhas de uma análise científica do processo administrativo, visando revelar seus traços conceituais, esse é o objetivo dessa exposição. A execução desse propósito dar-se-á em três etapas: na primeira será analisada a natureza do processo a partir das discussões traçadas no campo do Direito Processual Civil, área em que o tema foi abordado com maior profundidade; fixado o conceito de processo e sua natureza jurídica, passar-se-á a segunda etapa, buscando. então, os traços conceituais do processo administrativo. Na terceira etapa, ao final da investigação

1 Mencionam-se as obras de FERRAZ, Sérgio: DALLARI, Adilson Abreu. Processo Administrativo. São Paulo: Malheirus, 2001; SIMÕES, Mônica Martins Toscano. O processso administrativo e a invalidação dos atos viciados. São Paulo: Malheiros. No prelo: PORTA. Marcos. Processo administrativo e o devido processo legal. São Paulo: Quartier Latin. 2003.

2 Farta é a jurisprudência do Supremo Tribunal Federal, responsável por diretrizes importantes: no $R E 368441 \mathrm{AgR} / \mathrm{SP}$. relator Min. Maurício Correa, julgado em 19.04.03, decidiu-se que é legítima a exigência de depósito prévio como pressuposto de recorribilidade em processo administrativo fiscal: no $R E 342593 \mathrm{AgRSP}$, relator Min. Maurício Correa, julgado em 17.09.02, decidiu-se que a Administração pode anular seus próprios atos quando eivados de vícios, desde que respeite o direito adquirido e o ato jurídico perfeito e instaure processo administrativo garantindo ao prejudicado o exercício do contraditório; no AI 24I201 AgR/SC. Rel. Min. Celso de Mello, julgado em 27.08.02, decidiu-se que em processo administrativo impōe-se a fiel observância a de devido processo legal; no $M S$ 2292//SP, Rel. Min. Carlos Velloso, julgado em 05.06.02, decidiu-se ser dispensável no processo administrativo a presença de advogado; no Pet $2598 \mathrm{AgR} / \mathrm{CE}$. Rel. Min. Ellen Gracie, julgado em 23.04.02, decidiu-se ser constitucional a excepcionalidade da atribuição de efeito suspensivo aos recursos em processo administrativo; no MS 23654/SP. rel. Min. Néri da Silveira, julgado em 13.03.02, decidiu-se que a notificação ou comunicação prévia para realização de vistoria é elemento imprescindível para a validade do processo administrativo referente à desapropriação para reforma agrária. 
da verdadeira ontologia do processo administrativo, examinar-se-ão os princípios que 0 alicerçam.

Procurar-se-á enfrentar os chamados "lugares comuns", que tanto retardam o desenvolvimento científico. Mais do que posições inovadoras, busca-se tão-somente a reflexão. Os resultados desta, sem desprestigiar os grandes doutrinadores, antes disso, só os reverencia. As conclusões, se verdadeiras, só serão possíveis graças ao que por eles foi escrito a respeito do tema. Se falsas, que ao menos sirvam para fomentar outras reflexões.

\section{O Processo}

\subsection{Teorias sobre a natureza jurídica do processo civil}

Muito já se escreveu no Direito Processual Civil sobre a natureza jurídica do processo. Várias correntes e posições surgiram ao longo dos anos. Apesar de existir, hoje, no Brasil, posição majoritária, nem por isso é possível considerá-la pacificada. É, no entanto, nesse ramo da Dogmática Jurídica em que mais se discutiu o assunto. Por força disso é nele que devem ser buscados subsídios para um correto entendimento sobre a natureza jurídica do processo.

O processo já foi considerado contrato, quase-contrato, relação jurídica, situação jurídica, entidade jurídica complexa, instituição e procedimento. ${ }^{3}$ Quatro dessas correntes estão, hoje, superadas. O processo civil foi considerado contrato por força de seus primórdios: na primeira etapa do Direito Romano só havia processo se houvesse acordo entre as partes. Na verdade, o que havia era uma arbitragem. Com o monopólio da jurisdição pelo Estado. a teoria contratual adquiriu valor puramente histórico. Nos séculos XVIII e XIX, diante da debilidade da concepção contratual, desenvolveu-se a doutrina do quase-contrato judicial. Partia-se de uma eliminação: se o processo não era contrato, nem delito, nem quase-delito, só podia ser quasecontrato. Analisavam-se as quatro fontes de obrigações existentes e escolhia-se a menos imperfeita. Com a desvinculação do processo do direito privado tornou-se despropositado buscá-lo entre as fontes das obrigações privadas. Em sentido rigoroso, aliás, poucas são as obrigações no processo e as que existem são decorrentes do direito material. A teoria da entidade jurídica complexa também foi facilmente afastada. Por força dessa teoria, sob o ponto de vista normativo, o processo é uma relação jurídica complexa; sob o ponto de vista estático. é uma situação jurídica complexa e sob o ponto de vista dinâmico é um ato jurídico complexo. Ninguém

3 Vide uma completa sinopse dessas correntes e respectivals críticals em COUTURE, Eduardo J. Fundamentos del Derecho Procesal Civil. 4ta. ed. Montevideo: IBef, 2002, p. 101 et seq. Vide também CINTRA, Antonio Carlos de Araujo: GRINOVER, Ada Pellegrini; DINAMARCO, Cândido Rangel. Teoria Geral dó Processo. 11 ed. São Paulo: Malheiros, 1995, p. 278 el seq. Os autores, ao contrário do exposto acima, não mencionam o procedimento como uma concepção autônoma. 
nega que o processo seja uma entidade complexa, mas a teoria peca por ser pouco esclarecedora, frustrando os objetivos da Ciência: a complexidade é insuficiente para caracterização precisa do objeto. A teoria da institulu̧ão juridica, por fïm, também foi afastada pela doutrina pela imprecisão do conceito de instituição, palavra que possui extremada ambigüidade. Em sentido genérico consiste em estabelecimento. criação, organização, ${ }^{4}$ podendo, nesse sentido, considerar-se o processo como uma criação do direito para atingir um de seus fïns. O conceito peca igualmente por ser pouco esclarecedor. Em sentido específico, a teoria institucional perde-se nos múltiplos significados atribuídos a palavra. As três teoriats restantes merecem considerações à parte: as teorias da relação e da situação jurídicas e a teoria do procedimento.

\subsection{A teoria da relação jurídica de Oskar von Bülon: A teoria da sinuação juridica de James Goldschmidt}

A teoria da relação juridica é atualmente majoritária, tanto no Brasil como no exterior. Surgiu em 1868 com a edição da obra de Oskar von Bülow denominada "Teoria das Exceçôes e dos Pressupostos Processuais". . Afirmou com todas as letras: "o processo é uma relação de direitos e obrigações recíprocos, ou seja, uma relação jurídica" ? A assertiva teve extraordinária importância para o Direito Processual na medida em que vislumbrou uma relação jurídica distinta da relação jurídica material, elevando o Direito Processual ao patamar de ciência autônoma. ${ }^{\vee}$

James Goldschmidt submeteu à severa crítica a teoria da relação jurídica." $\mathrm{O}$ conceito de "relação jurídica" tomado por Biilow era o adotado na época, repetido até os dias de hoje, próprio do direito obrigacional privado: vínculo entre o credor (sujeito ativo) e o devedor (sujeito passivo) em que aquele é titular de um direito subjetivo e este de um dever jurídico. Relação jurídica, nesse sentido, é sinônima

4 HOUAISS, Antônio; VILLAR, Mauro de Salles. FRANCO, Francisco Manoel de Mello (Editores). Dicionário Houaiss da Lingua Portuguesa. Elaborado no Instituto Antônio Houaiss de Lexicografiat. Rio de Janeiro: Objetiva, 200l, p. 1627.

5 Uma das teorias institucionalistas mais famosas é a de Maturice Hauriou. Para o jus-fïlósofo instituição é "uma idéia de obra ou de empresa que se realiza e dura juridicamente em um meio social". La Teoria de la Instinacion y de la Fundación: ensilyo de vitalismo sociat. Tradução do francês, prólogo e bibliogratīa do alutor por Arturo Enrique Sampay. Buenos Aires: Abeledo-Perrot. 1968 , p. $39-40$.

6 BULOW, Oscar Von. Teoria das Exceçōes e dos Presstupostos Processtadis. Tradução e notas de Ricardo Rodrigues Gama. Campinas: LZN, 2003. O próprio Bülow afirma, logo na primeira nota de rodapé de sua obra, que não foi o primeiro a associar a relação jurídica ao processo. Atribui o feito a Bethmann-Hollweg. Foi, todavia, sem dúvida alguma, o primeiro a sistematizar a teoria.

7 Ibid., p. 1.

8 Nunca é demasiado ressaltar que a relativa autonomia dos Ramos da Dogmática Jurídica só existe metodologicamente como corte indispensável para o desenvolvimento científico. Ontologicamente nenhum ramo da Dogmática é dotado de autonomia.

9 GOLDSCHMIDT, James. Direito Processual Civil. Tradução de Lisă Pary Scarpal. 1. ed. Campinas: Bookseller. 2003, p. 13 et seq. 
de obrigação. ${ }^{10} \mathrm{O}$ termo obrigação designa tanto o dever do sujeito passivo correlato a um direito de crédito (acepção estrita). quanto o vínculo obrigacional, ou seja, a relação obrigacional como um todo (acepção ampla).

Entendido o significado de relação jurídica na teoria de Bülow não há como negar a procedência das críticas de Golsdchmidt. Aos litigantes. atirmou este. não toca nenhuma obrigação de natureza processual. A obrigaçìo de decidir atribuída ao juiz não é processual e não é obrigação (acepção estritil). É um dever jurídico de um agente público cumprir sua função, decorrente do vínculo estatutário. $O$ dever do Estado em efetivar a prestação jurisdicional não é processual, nem obrigação (acepção estrita), decorre de uma relação política entre o Estado e seus cidadãos. As situações processuais não se constituem em obrigaçôes" e sim em ônus.

Ônus é a posição em que se encontra determinado sujeito, chamado onerado, de obter uma vantagem prevista em lei. Para obtençĩo dessa vantagem, o onerado tem que adotar o comportamento exigido pela lei. Se não o adotar. não fáz jus à vantagem prevista. É uma situação de necessidade jurídica: se o onerado quiser obter a vantagem prevista em lei. deve adotar o comportamento por elit exigido. Difere, portanto, da obrigação. A obrigação também é uma situação de necessidade jurídica, pois o comportamento do sujeito passivo, a prestação, também é exigido pela lei. Se adotar o comportamento previsto na lei, no entanto, não obtém uma vantagem para si, mas para outrem, para o sujeito ativo, titular do direito subjetivo correspondente. Tanto a obrigação guanto o ônus são. assim. situações de necessidade jurídica, ambos provocam uma vantagem, mas neste a vantagem é própria, naquela é alheia. A não adoção do comportamento previsto leva a consequiências distintas: na obrigação, a não adoção do comportamento previsto gera uma consequiência jurídica, a lesão do credor, facultado-se a este, em face da lesĩo sofrida. cobrar o cumprimento da obrigação ou o pagamento de perdas e danos pela inexecução: no ónus, a não adoção do comportamento previsto leva a uma consequiência econômica: não obtenção da vantagem prevista na norma. Sintetizando: as situaçōes processuais, de regra, constituem-se em ônus, ou seja, em poderes jurídicos de exercer determinados comportamentos necessários para obtenção de vantagens previstas em lei. ${ }^{\text {?2 }}$

A crítica de Goldschmidt mereceu acolhida. O processo não pode ser tomado como relação jurídica, caso se tome esta como sinônima de obrigaçuão (sentido

10 O conceito é ainda utilizado no Direito Privado. Vide GOMES, Orlande. Obrigaçües. 10. ed. Rio de Janeiro: Forense. 1995. p. II et sec. No passado era tomado. entretanto, como instituto da Teoria Geral do Direito sobre o qual se estruturava todo o ordenamento. Preponderava uma concepção patrimonialista de todo o direito. Hoje. esse conceito de relação jurídica é restrito ao direito patrimonial privado.

11 Discute-se a existência de duas raras exceções, obrigaç̧oes de natureza processual: a obrigação de pagar os ônus de sucumbência e a obrigação de lealdade processilall. Parece correto, no entanto, afirmar que as normas referentes a essas obrigaçōes são de direito material. Nesse sentido DINAMARCO, Cândido Rangel. Execução Civil. 6. ed. rev. e atual. São Paulo: Malheiros, 1998, p.119. 12 A conceituação de ônus e a diferenciaçāo deste da obrigação teve por base a transcrição de gravação em áudio da 18“. aula do Curso de Direito Processual Civil ministrado pelo Min. Antonio Cezar Peluso na Pontifícia Universidade Católica de São Paulo. no ano de 1996. 
amplo), vínculo que une o sujeito ativo ao passivo em que aquele é titular de um direito subjetivo e este de uma obrigação (sentido estrito). A partir desse raciocinio, o ínclito jurista alemão defendeu a teoria da situação jurídica: se não há obrigações processuais, os vínculos entre as partes não são propriamente relaçōes jurídicas e sim situações jurídicas, quer dizer " situações de expectativa, esperanças da conduta judicial que há de produzir-se e, em última análise. da decisão judicial futura". 13 Em síntese, o processo consistiria em situações jurídicas, ou seja, em expectativas, possibilidades e ônus.

A teoria da situação jurídica defendida por Goldschmidt não é atualmente aceita, não pela improcedência de sua crítica, mas pelos avanços científicos da Dogmática Jurídica. Um novo conceito de relação jurídica vigora atualmente e esse conceito permitiu a reformulação da teoria da relação jurídica processual. Antes de anatisá-la. entretanto. necessário tratar sucintamente da teoria que iguala o processo a procedimento.

\subsection{O processo como procedimento}

Nunca se questionou que o processo é um procedimento. O próprio Bülow afirmou:

O processo é uma relação jurídica que avança gradualmente e se desenvolve passo a passo. [...] Porém, nossa ciência processual deu demasiada transcendência a este caráter evolutivo. Não se conformou em ver nele somente uma qualidade importante do processo, mas desatendeu precisamente outra não menos transcendente ao processo como uma relação de direito público, que se desenvolve de modo progressivo, entre o tribunal e as partes, destacou sempre unicamente, aquele aspecto da noção de processo que salta aos olhos da maioria: sua marcha ou adiantamento gradual, o procedimento: $[\ldots]^{1+}$

E, logo adiante, concluiu de forma peremptória: " poder-se-ia, segundo o velho uso, predominar o procedimento na definição do processo, não se descuidando de mostrar a relação processual como a outra parte da concepçĩo." 15

James Goldschmidt também nunca negou que processo é procedimento. Afirmou textualmente: "o processo civil é um procedimento, um caminhar concebido, desde a Idade Média, para aplicação do Direito". ${ }^{16}$

Etimologicamente "procedimento" decorre da junção do verbo latino procédo, is, cessi, cessum, dère - ir na frente, avançar, progredir, com o formador de substantivos derivados de verbos - mentu. "Processo" por sua vez vem do substan-

13 GOLDSCHMIDT, 2003, p. 21. Vide uma crítica à tcoria da situação jurídica de Goldschmidt em DINAMARCO, Execução Civil. p. 120-121; COUTURE. 2002, p. 110-113.

14 BÜLOW, 2003, p. 6-7.

15 BÜLOW, 2003, p. 8.

16 GOLDSCHMIDT. 2003, p. 13. 
tivo latino processus, us - ação de adiantar-se. movimento para diante, marcha. Registra-se também que "processo" decorre do supino de procedère ${ }^{17}$ Percebe-se, assim, que, ao menos etimologicamente, faz sentido considerar sinônimos processo e procedimento.

A particularidade do que aqui se chamou teoria do procedimento é que para alguns juristas processo não é nem relação jurídica, nem situação jurídica. É, tãosomente, procedimento. O Ministro Cezar Peluso ao afastar todas as teorias sobre a natureza jurídica do processo, afirmou categoricamente: processo não é relação jurídica, nem situação jurídica, é tão só procedimento. Na Teoria Geral do Direito, segundo o nobre magistrado, há efeitos jurídicos que decorrem da prática de apenas um ato, são os chamados atos instantâneos: e há efeitos jurídicos que decorrem da prática de vários atos. Quando a fattispecie normativa for composta de vários elementos, de modo que todos devam estar presentes para que se produza o efeito jurídico previsto, há o chamado procedimento ou processo. Daí o singelo conceito: "processo ou procedimento é um conjunto de atos necessários para obtenção de um produto". E, por consequiência, o conceito de processo civil: "processo é o procedimento necessário para produção de sentença". A processualidade tem por característica não ser aleatória: consiste numa série de atos legalmente ordenada, de modo que cada ato é antecedente do posterior e consequiente do anterior. ${ }^{18}$

O eminente Cezar Peluso foi um dos raros juristas que, de forma explícita e clara, afastou-se da teoria da relação jurídica para sustentar o que se poderia chamar de teoria do procedimento. Todavia, sem uma negação explícita da teoria da relação jurídica, muitos doutrinadores, ao conceituarem o processo civil, enunciam um conceito similar ao enunciado pelo Ministro. ${ }^{19}$

A teoria do procedimento pode. talvez, ser admitida sem reservas no direito estrangeiro ou no direito brasileiro pretérito. No direito pátrio atual há um entrave dogmático insuperável: o art. 24, inciso XI, da Lei Maior. Esse dispositivo determina competir à União, aos Estados e ao Distrito Federal legislar concorrentemente sobre "procedimentos em matéria processual". Por uma regra elementar e pacificamente aceita de hermenêutica, na lei, e muito mais na Constituição. não se presumem palavras inúteis. Se processo fosse tão-somente procedimento, o dispositivo seria inútil, pois não haveria diferença entre matéria de procedimento e matéria processual. Do dispositivo, a contrario sensu, não se extrai outra conclusão possível a não ser a de que: no Brasil processo e procedimento são institutos distintos.

17 HOUAISS; VILLAR, 2001, p. 2.302-2.303.

18 Supra, nota 12.

19 Luiz Guilherme Marinoni e Sérgio Cruz Arenhart assim o conceituam: "A jurisdição é exercida pelo juiz, devidamente investido no poder do Estado, e por meio do processo. Em outras palavras, o processo é o instrumento pelo qual o Estado exerce a jurisdiçāo. Se o processo é o instrumento, e se para o exercício da jurisdição por meio do processo são traçados, pela lei, vários procedimentos - que devem estar de acordo com as normas e valores constitucionais -, o processo pode ser definido como o procedimento que. atendendo aos ditames da Constituição da República, permite que o juiz exerça a sua função jurisdicional". Manual do Processo de Conhecimento: a tutela jurisdicional através do processo de conhecimento. São Paulo: RT, 2001, p. 56. 
A não identidade entre os dois termos decorrente da diç̧ão do inciso II do art. 24 mencionado não impede que entre eles haja uma relação de inclusão. Processo é procedimento: a matéria processual, ao menos no ordenamento jurídico brasileiro. abrange a matéria procedimental mas nesta não se esgota. Processo é procedimento e alguma coisa a mais.

\subsection{Processo como procedimento contraditórios}

Há doutrinadores que não aceitam as teorias da relação e da situação jurídicas. Insistem em colocar a ênfase do conceito de processo no procedimento, mas acrescentam: só é processo o procedimento em que vigora o contraditório. Essa tendência é registrada por Cândido Rangel Dinamarco:

É verdade que as mais modernas tendências doutrinárias dos dias que correm propugnam por uma verdadeira reabilitação metodológica do procedimento, afirmando que ele se situa no núcleo do conceito de processo. válido para toda a teoria geral. O processo, nessa visão. não é apenas o instrumento da jurisdição, tendo espectro muito mais amplo. Ele reside em todo processo realizado em contraditório, repudiada nesse sistema a validade metodológica da relação jurídical processual. ${ }^{20}$

Processo, assim, seria conceituado como todo procedimento realizado em contraditório. Para o correto entendimento dessa recente doutrina exige-se que o uso do termo "contraditório" seja bem entendido. Tudo indica que a palavra não é utilizada pelos que a defendem em sentido rigorosamente técnico.

Essa tendência doutrinária intensificou-se a partir da célebre obra de Nicklas Luhman denominada "Legitimação pelo procedimento". Reabilitou-se o procedimento como conceito central do processo. É através do procedimento, garantindo-se nele a participação dos interessados, que se tornat legítima a decisão tomada pelos detentores do poder. ${ }^{21}$ Tércio Sampaio Ferraz Jr., em primorosa apresentação à tradução brasileira da obra de Luhman, explica que a legitimação do procedimento não está em convencer os participantes do acerto da decisão tomalda, mas em

20 DINAMARCO. Cândido Rangel. Os institutos fundamentais do Direitos Processual. In Fundamentos do Processo Civil Moderno. 4. ed. Sĩo Paulo: Malheiros. 2001. Tomo I. p. 76. Vide também DINAMARCO. Execução Cisil, p. 121-122. O alutor menciona como defensor dessia posição Fazzalari.

21 Luhman, na fiumosa obra, não dá o enfoque que os juristas, a partir dela. costumam atribuir-lhe. De fato, logo no prefácio o sociólogo alemão afirma: "Este livro não trata, portanto, de 'legitimar' a instituição do processo legal através da justificação de uma função; trata, sim, da revelação do problema que a justificição resolvia e isso é facilmente omitido porque não se identifica com problemas que se procuram resolver nos processos legais por meio das decisões". LUHMAN, Nicklas. Legitimação pelo procedimento. Tradução de Maria da Conceição Corte-Real. Brasília: Editora Universidade de Brasília, 1980, p. 13. Se a obra não dá esse enfoque. sem dúvida nenhuma contribuiu para que se chegasse a ele. 
"imunizar a decisão final contra as decepções inevitáveis".? Isso ocorre porque a participação no procedimento reduz o conflito, enfraquece o confronto. na medidat em que quem participou do processo de produção tem mais facilidade em aceitar o produto. Há uma legitimação do exercício do poder pela participação dos interessados no procedimento em que o poder é exercitado. O procedimento passa. assim. a ser um instrumento da democracia. O poder exercido sem a participação dos interessados, ou seja. sem um processo. é arbitrário. ${ }^{2.3}$

Ainda que brevemente, necessário fixar os contornos do princípio do contraditório. Quando um ato. para ser realizado, necessita da ocorrência de vários atos antecedentes tem-se um procedimento. As partes podem participar desse procedimento, contribuindo para produção do ato final, podem apresentar sua versão, podem apresentar documentos, provas, podem. enfim. possibilitar o proferimento do ato final. Ainda assim pode não haver contraditório. Contraditório exige a participação, mas não se confunde com ela: significa que a caldi ação de uma parte corresponda a possibilidade de reação da outra. O contraditório implica num método dialético de dicção e de contradição, pressupõe a existência de um conflito de interesses em que as partes tenham interesses contrapostos, de modo que nunca haja a supremacia de uma ação sem a possibilidade de uma contra-ação ou de uma reação. Num processo contraditório as ações linguiísticas sempre são contrapostas; assegura-se o equilíbrio da possibilidade de uma dição e de uma contradição: nele há. enfim, um processo agônicu. ${ }^{24}$

Se essa corrente utiliza o termo contraditório nesse sentido, todos os procedimentos de jurisdição voluntária não seriam processo. Enquanto não citado o réu haveria tão somente procedimento. Processo só existiria quando houvesse essa situação agônica. esse equilíbrio de posiçōes contrapostas em que a cada ação há oportunidade de reação contrária. Parece ser isso o que afirma Cândido Rangel Dinamarco ao dizer que: "nem todo procedimento é processo. (...) o critério para a conceituação é a presença do contraditório". ${ }^{25}$ Contraditório, aí no entanto, é sinônimo de direito à participaç̧ão e não de contraditório no sentido técnico da palavra. ${ }^{26}$

22 LUHMAN. op. cit. p. 4.

23 DINAMARCO. A Instrumcrnalidade de procisise. p. 15y

24 A conceituação de contraditório teve por base transcriçăio a partir de gravação em áludio da 6 ". aula do Curso de Direito Processual Civil ministrado pelo Min. Antonio Cezar Peluso na Pontifícia Universidade Católica de São Paulo, no ano de 1996.

25 DINAMARCO. op. cit.. p.161.

26 Ressalvat-se que esse entendimento não é explicitamente afirmado pelo autor. Em várias passagens, no entanto, tudo leva a crer que o ilustre processualista utiliza-se da palavra contraditório em sentido rigorosamente téchico. Fala, na página 156, de "paridade em armas". Reporta-se ao seu texto Princípio do Contraditório e sua Dupla Destinação. In: Fundamentos do Processo Civil Moderno. 4. ed., São Paulo: Malheiros, 2001. Tomo I, p. 124. Neste, o autor identifica o contraditório com o binômio informaçăo-reação. em que a primeira é neesessuria e a segunda é possível. Tudo indica, assim. que a palavra tenha. ao menos pelo processualista, sido intencionalmente utilizada. Se assim for, fica registrada a divergênciil. 
De fato, o benemérito magistrado juntamente com Antonio Carlos de Araujo Cintra e Ada Pelegrini Grinover ao analisarem a jurisdição voluntária, primeiro afirmam que nela "não há conflito de interesses entre duas pessoas, mas apenas um negócio. com a participação do magistrado". E. alén disso. "que não havendo oposição de interesses em conflito. não seria adeçuado falar em partes". ${ }^{27}$ Mas, apesar da inexistência de contraditório, ao menos nos casos em que não há controvérsia, atribuem-na o conceito de processo: "não há por que restringir à jurisdição contenciosa os conceitos de parte e de processo (mesmo porque este. em teorial geral. vale até para funções não-jurisdicionais e mesmo não-estatais)". ${ }^{28}$

Uma separação consensual (artigos 1.120-1.124 do Código de Processo Civil), de fato, não é um mero procedimento, é um processo. Despachada ou, nos locais em que há mais de uma vara, distribuída a petição inicial (Código de Processo Civil, art. 263) já existe processo, independente da citaçĩo do réu. Para que haja processo, além do procedimento, necessário, não o contraditório, mas o direito à participação. É o direito de participação dos interessados que faz do procedimento um processo. Esse direito decorre de un vínculo entre duals situaçòes jurídicas, a situação do agente estatal encarregado de exercício do poder e a do interessado.

Assim, quando se afirma que processo é todo procedimento realizado em contraditório, quer-se dizer que processo é todo procedimento em que se garanta o direito de participação aos interessados. Leia-se o que dic Dinamarco:

Procedimento e contriditório fundem-se numa unidade empírica e somente mediante algum exercício do poder de abstração pode-se perceber que no fenômeno "processo" existem dois elementos conceitualmente distintos: à base das exigências de cumprimento dos ritos instituídos em lei está a garantia de participaçĩo dos sujeitos interessidos, pressupondo-se que cada um dos ritos seja desenhado de modo hábil a propiciar e assegurar essa participação.

(...)

A partir dessa visão do processo como entidade complexa pode-se agora perceber que ele inclui toda uma técnicia, indispensável para a participação dos sujeitos em conflito. A participação, em si mesma, é o contraditório. ${ }^{2 y}$

Contraditório, sem desprestigiar o entendimento em contrário, nāo é sinônimo de participação. Pressupõe esta mas não a esgota. Nos procedimentos de jurisdição voluntária em que não há controvérsia: em todos os casos em que o contraditório é posposto $;^{30}$ na parte dos procedimentos que vai da propositura da ação à citação do réu, em todos esses casos há participação. mas não há contraditório. Neles existe, sem sombra de dívida, mais do que mero procedimento.

27 CINTRA: GRINOVER: DINAMARCO, 1995, p. 151-152. Ressalvam a possibilidade de em alguns casos haver controvérsia, incidindo. por causa delat, o princípio do contraditório.

28 CINTRA: GRINOVER: DINAMARCO. 1995. p. 152.

29 DINAMARCO, A Instrumentalidade do processo, p. 162.

30 O contraditório é posposto én todos os ciasos de concessão de liminar inaudita altera parte. 
Para que haja processo civil, nos termos desse entendimento, basta a existência de: 1) um órgão ou juízo no exercício de sua competência e 2) a existência de um pedido, de uma demanda ou, em outras palavras, de uma petição inicial em que se faça um pedido ao juiz. Esses são os verdadeiros pressupostos processuais. Tudo o mais é indevidamente chamado de pressuposto. ${ }^{31}$

Com a apresentação de uma petição inicial em que se faça um pedido a um órgão ou juízo investido na competência jurisdicional surgem duas situaçōes jurídicas, de certo modo vinculadas uma a outra: a do agente político em exercício no juízo ou no órgão, que tem, entre outros, o dever jurídico de dar uma resposta ao pedido, ainda que seja para considerar inepta a petição, e a do requerente em ter seu pedido apreciado. ainda que seja para ver indeferida sua petição inicial por inépcia. O que faz do procedimento um processo é o direito à participação: ou seja, o conjunto de situações jurídicas atribuídas ao interessado que lhe permitem influir na obtenção do produto, fruto do exercício do poder.

Bem entendida a teoria do procedimento realizado em contraditório, tomando-se este como direito à participação, percebe-se que referida teoria nada mais é do que a nova formulação da teoria da relação jurídica processual (a seguir examinada). Muda-se apenas o enforque. Daí afirmar Dinamarco: "vê-se, pois, que definir o processo mediante associação do procedimento ao contraditório (aqui chamado direito à participação), ou inserir-lhe no conceito de relação juridica processual são apenas dois modos diferentes de ver a mesma realidade". 32

Em síntese: a teoria do procedimento contraditório. corretamente entendida, é equivalente à nova formulação da teoria da relação jurídica processual, trata-se apenas de outro enfoque da mesma concepção. Processo é um mecanismo democrático de tomada de decisões, ou seja, de exercício do poder. Apóia-se sobre uma idéia básica: o exercício do poder só é legítimo se possibilitar a participação dos interessados. Isso se traduz em dois elementos indissociáveis: 1) para que haja a participação dos interessados no exercício do poder o ato de decidir não pode ser instantâneo, o direito à participação exige que o ato de decidir decorra de vários atos, seja o produto final de uma série de atos. exige. portanto. um procedimento. 2) Essa participação exige uma relação entre os interessados e o Estado. representado pelo agente incumbido de decidir, uma relação continuativa formada por uma série de situações jurídicas ativas e passivas.

31 Pressuposto é toda circunstância necessariamente antecedente de outra. Ora, havendo um órgão jurisdicional no exercício de sua competência e uma petiçaio inicial veiculando um pedido. há processo. Tudo o mais vem depois de sua constitução e. assim. não pode ser considerado pressuposto. É o pensamento do Min. Cezar Peluso. Cf. transcriçĩo de gravação em áudio da $19^{\circ}$. aula do Curso de Direito Processual Civil ministrado na Pontifícia Universidade Católica de Sĩo Paulo, no ano de 1996.

32 DINAMARCO. A Instrumentalidade do Processo. p. 163. 


\subsection{A nova formulação da teoria da relação juridica processual}

Como já atirmado. a Teoria Geral do Direito tomou o conceito de relação obrigacional como instituto fundamental do direito. aplicando-o a todos os ramos jurídicos, fruto de uma visão acentuadamente patrimonialista. Por força disso. na primeira formulação da teoria da relação jurídica processual esta era tomada cono sinônimo de obrigação (em sentido amplo): vínculo jurílico que liga o sujeito ativo, titular de direito subjetivo, ao sujeito passivo. titular de obrigação lem sentido estrito). A crítica de Goldschmidt mantém-se inabalátel: é impossível considerar o processo uma obrigaçio (em sentido amplo). A Teoria Geral do Direito, sobretudo a partir do desenvolvimento do conceito de situação jurílica. desenvolveu novo conceito de relação juridica. A partir dele a teoria da relação jurídica processual é liberta da crítica do venerável jurista alemão.

Ainda que sucintamente, necessário o exame do conceito de situaçăo juridica. hoje vigorante. Trata-se de un conceito geral. abarcante de vários conceitos: direito subjetivo, poder jurídico, interesse legítimo, obrigação, ônus, sujeição, consistentes em formas de avaliar o comportamento. Segundo Pietro Perlingieri ${ }^{33}$ as situações jurídicas devem ser consideradas sob seis aspectos que, unitariamente entendidos. dão a exata dimensão delats: 1) sob o perfil do efeito, toda situação encontra sua origem num falto juridicamente relevante; 2) sob o perfil do interesse, do ponto de vista objetivo toda situação refere-se a um interesse que, essencial a sua existência, é seu núcleo vital e característico; 3) sob o perfil dinâmico, o interesse reconhecido a um sujeito traduz-se. no momento de seu exercício. em comportamentos e as situações dão forma conceitual a esses comportamentos: 4) sob o perfil do exercício da situação. para que este se dê é preciso a manifestação de vontade de um sujeito, não necessariamente do titular do interesse: 5) Sob o perfil funcional, a cada situação o ordenamento atribui uma função social..$^{3+}$ o interesse é tutelado não somente enquanto atende ao interesse do titular mas também ao da coletividade, ${ }^{35}$ 6) por fim, sob o aspecto normativo ou regulamentar. a situação constiui efeito de norma de conduta $^{36}$ que atribui ao sujeito, no interesse próprio e/ou alheio. ou poder ou dever

33 PERLINGierI, Pietro. Perfis don Dircito Civil: introdtçăo au Dircito Civil Constitucional. Tradução de Maria Cristina De Cicco. 2. ed. Rio de Janeiro: Renovar, 2002. p. 1U5. Registra-se que toda exposição sobre as situaçũo e a relação juridicas teve por base o pensamento do civilista italiano. com algumals alteraçòes.

34 Perlingieri refere-se ao ordenamento italiano, mals a assertiva aplica-se integralmente ao ordenamento brasileiro, sobretudo após a Constituição de 1988: á n que se extrai de uma interpretação sistemáticar, dentre outros, dos alts. 5".. XXIII e 170, III.

35 Dá observar o civilista italiano que, por força dessa configuração solidarisła do ordenanento constitucional, na maior parte das hipóteses o interesse dá lugar a umal situaçăo subjertiva complexa, composta tanto de poderes. quanto de ônus, deveres c obriğações. Nas situaçōes subjetivas complexas estão presentes momentos de puder e de dever, de modo que a distinção entre as situaçōes ativals e passivas não pode ser entendida de mudo absoluto. Ibidem. p. 107.

36 Discorda-se açui do autor. A situação é um dos efeitos da norma de conduta e não a norma em si. 
de realizar um comportamento, ou poder ou dever de não realizá-lo. A partir da congruência desses seis aspectos tem-se delimitado o conceito de situação jurídica.

A velha assertiva da Teoria Geral do Direito de que o ordenamento jurídico é um sistema de relações mantém-se. Relação jurídica passa, no entanto, a ser a ligação entre um interesse e outro interesse, entre uma situação jurídica determinada ou determinável e outra situação jurídica. A relação jurídica é uına relação entre situações jurídicas. $O$ conceito anterior de relação jurídica, sinônimo de obrigação em sentido lato, passa a ser apenas uma das muitas espécies de relações jurídicas existentes. ${ }^{37} \mathrm{Na}$ relação jurídica não há tão-somente o direito subjetivo e a obrigação em sentido estrito. Segundo essa concepção não há mais que se falar, a não ser em termos quantitativos, em posições ativas e passivas, pois as ditas ativas compreendem também deveres e obrigações e aquelas ditas passivas contêm freqüentemente alguns direitos e poderes. Daí afirmar Perlingieri:

A relação não está na ligação entre direitos subjetivos, de um lado, e dever ou obrigação, do outro. É difícil imaginar direitos subjetivos que não se justificam no âmbito de situações mais complexas, das quais fazem parte também deveres, ônus, obrigações, isto é, posições que, analiticamente consideradas, podem ser definidas como passivas. A relação sob o perfil estrutural é relação entre situações complexas, que pode ser de simples correlação (collegamento) (assim, entre potestà e interesse legítimo), ora, e são as hipóteses mais freqüentes no campo do direito civil, de contraposição e de conflito (assim, nas obrigações onde a situação debitória contrapõe-se àquela creditória). ${ }^{38}$

Relação jurídica é, portanto, "o nexo que liga dois ou mais sujeitos, atribuindo-lhes poderes, direitos, faculdades e os correspondentes deveres, obrigações, sujeições, ônus" ${ }^{39}$ Com essa reformulação do conceito de relação jurídica, caí por terra a crítica de James Goldschmidt. O processo passa a ser visto como uma complexa ligação entre sujeitos: autor, réu, exequiente, executado entram em relação com o Estado. Nessa relação há, referentemente a cada um dos sujeitos do processo, inúmeras situações jurídicas complexas: poderes, faculdades, deveres. sujeições, ônus. ${ }^{40}$

37 O velho conceito de relaçāo jurídica, entretanto. ainda é utilizado por muitos juristas. O célebre Paulo de Barros Carvalho vale-se dat estrutura da relação obrigacional para explicar a relação jurídico-tributária. Diz expressamente: "Para a Teoria Geral do Direito. relaçăo jurídica é definida como o vínculo abstrato, segundo o qual, por força da imputação normatival uma pessoa. chamada de sujeito ativo, tem o direito subjetivo de exigir de outrat denominada sujeito passivo. o cumprimento de certa prestação". Curso de Direiro Tributário.14. ed.. rev. e atual. São Paulo: Saraival. 2002, p. 281. Esse conceito, sem desprestigiar o nobre jurista, ao menos como cattegoria geral, está superado.

38 PERLINGIERI, 2002, p. 116.

39 DINAMARCO. Execução Civil, p. 117.

40 DINAMARCO. loc. cit. 
Há grande divergência, todavia, no que tange à estrutura dessa relação, existindo três correntes: Kohler defendeu tratar-se de relação linear, entre o autor e o réu; Hellwig. relaçäo angular. entre o autor e o Estado-juize entre o réu e o Estado-juiz: por fim, segundo Wach trata-se de relaçăo triangular, relações do autor com o Estado. do Estado com o réu e do autor com o réu." A tese de Kohler. reminiscência dat concepção civilística da ação, é pacificamente negada. A ação não é mais tomada como um direito do autor contra o réu. é exercida em face do Estado. Observil-se. contudo, a existêncial antes da citação do réu. de relação linear entre o demandante e o Estado-juiz. Segundo a tese de Wach, hoje majoritária, ${ }^{\text {t? }}$ a relação entre o autor e o réu decorreria das obrigações de pagar ônus de sucumbência e de lealdade processual. Ocorre que, conforme já defendido acima. referidas obrigações são de direito material e não de direito processual. Por força disso, correto é conceber a relação jurídica processual como uma relação de estrutura angular, em que a relitção é entre cada uma das partes e o Estado-juiz. mesmo que. reflexamente, a relação influa na situação da parte contrária. ${ }^{+3}$

A doutrina discrimina seis características da relação jurídica processual. ${ }^{4}$ 1) Complexidade - ats relações são simples quando há apenas uma posição jurídica ativa e uma passiva $a^{45}$ e complexas quando há uma pluralidade destas e/ou daquelas. $\mathrm{Na}$ relação jurídica processual há uma série de situaçôes jurídicas complexas. 2) Progressividade, continuidade, dinamismo - nas relações complexas de duas uma: ou se acumula, desde logo, diversas posições jurídicas. ou passa-se de posição em posição pela ocorrência de fatos juridicamente relevantes. A segunda hipótese é a que ocorre no processo: caminha-se dialeticamente. através de uma sucessão de situações jurídicas que se substituem gradativamente. graças à ocorrência de atos e fatos processuais. O conjunto desses fatos é o procedimento. 3) Unidade - todas essas situações jurídicas são coordenadas a um objetivo comum. à ubtenção do produto final: prolação do ato estatal imperativo. Por força disso todas as situações jurídicas processuais, durante todo o procedimento, compõem apenas uma relação jurídica, há uma unidade teleológica. 4) Estrutura Angular - Segundo a doutrina, possui caráter tríplice, compondo-se de três sujeitos: demandante, demandado e Estado-juiz. ${ }^{46}$ A estrutura angular, no entanto, se aceita, contraria essa posição. Há duas relações jurídicas vinculadas: a relação entre o demandante e o Poder Público e a relação entre o demandado e o Poder Público. 5) Natureza Pública - o processo é um meio de exercício do poder estatal, sendo, assim, tipicamente de direito público.

41 Sobre as teorias vide COUTURE. 2002, p. 109-110; DINAMARCO, Execução Civil, p. 118-119.

42 É a posição de COUTURE. op. cit., p. 119.

43 É a posição de DINAMARCO, op. cit., p. 119.

$4 \ddagger$ CINTRA: GRINOVER: DINAMARCO, 1995, p. 290-291. DINAMARCO, Execuçũo Civil, p. $123-125$

45 Hoje. nos termos expostos, negal-se a existência de relaçóes simples. HH

46 É a posição de CINTRA: GRINOVER a DINAMARCO, 1995, p. 197. 
ainda que privada a relação de direito material. 6) Autônoma - para ter validade, a relação processual independe da relação de direito substancial.

Examinada. em detalhes. a relação jurídica processual, passa-se ao conceito de processo. Este é a síntese dessa relação progressiva e da série de fatos que determinam sua progressão. ${ }^{+7}$ É, como dito. um meio democrático de exercício do poder em que. através da relaçãa entre os interessados e o Poder Público. representado pelos agentes políticos encarregados de exercê-lo. sucedem-se vários atos, todos necessários ao ato final, vinculados ao mesmo desiderato, à prolação da decisão. Daí a indissolubilidade entre os dois institutos: em cada ato do procedimento surge nova situação jurídica em que o interessado participa da emissão da decisão estatal. O procedimento só existe para possibilitar a concretização dessa relação continuativa, estal só existe para possibilitar, através do procedimento. o exercício democrático do poder.

\subsection{Processo e Procedimento: diferenciaçũo}

Examinada a reformulação da teoria da relação jurídica processual, que aqui se adota integralmente, imperativo o reexame dogmático para melhor precisar a diferenciação entre o processo e o procedimento. O constituinte, ao distribuir as competências às entidades federadas, elaborou um sistema de difícil compreensão: no art. 22, I, estabeleceu ser competência privativat da União legislar sobre direito processual; no art. 24, incisos X e XI, estabeleceu ser competência concorrente da União, Estados e Distrito Federal legislar, respectivamente, sobre a criação, funcionamento e processo do juizado de pequenas calusas e sobre procedimentos em matéria processual. Não é o objeto desta análise o exame das competências, assunto complexo, não comportável nos limites destil exposição. Interessa aqui tão-somente delimitar as exigências dogmáticas referentes aos conceitos de processo e procedimento.

A leitura do referido inciso XI do art. 22 faz supor que o Constituinte inspirou-se numa antiga concepção, sustentada no passado por processualistas de renome do direito brasileiro, que tomava processo e procedimento como duas realidades absolutamente apartadas. Famosa, nesse sentido, é a lição de João Mendes Júnior para quem "uma coisa é o 'processo', outra coisa é o 'procedimento': o processo é a direção no movimento; o procedimento é o 'modo' de mover e a 'forma' em que é movido o ato". ${ }^{4 \gamma}$ Essa concepção, nos dias de hoje, é completamente inaceitável. Processo e procedimento são realidades indissolvíveis. Processo é, e isso não há mais dúvida, procedimento associado à relação jurídica. Há, assim, relação de inclusão, de continente-conteúdo: procedimento é um elemento estrutural do processo.

47 O conceito é de Dinamarco (Execução civil, p. 123).

48 MENDES JR., João. Dircito Judiciário Brasileiro. 2. ed..1918. p. 298 upud MARQUES. José Frederico. Elementos de Direito Processual Penal. Campinhas: Bookseller. 1997, v. 1. p. 348. A lição foi seguida pelo célebrc Frederico Marques. Op. cit., p. 348 et séq. 
Mas é obrigação do intérprete dar um sentido à norma. A Constituição impõe uma clara dissociação entre o processo e o procedimento, ao menos para o exercício da competência. Isso porque para legislar sobre procedimento. a competência da União limita-se a editar normas gerais. Os Estados e o Distrito Federal possuem competência suplementar e. caso a União não exerça sua competência, editando as normas gerais, têm competência plena para editá-las. Isso em relação à matéria procedimental, parte da matéria processual. Tudo o mais da matéria processual que não se restrinja aos procedimentos, ou seja, a disciplina da relação jurídica processual, é competência privativa da União. Estados e Distrito Federal não têm competência parà disciplinar a relação jurídica material. ${ }^{4950}$

Foi Edson Ribas Malachini, em precioso artigo. ${ }^{51}$ quem melhor enfrentou o problema. Visando delimitar com precisão quais os temas restritos ao procedimento, assim doutrinou:

As regras sobre competência; a exigência da citação e das intimações. atos de comunicação processual que se constituem em requisito fundamental do contraditório: as regras sobre os pressupostos processuais (inclusive sobre as nulidades) e as chamadas condições da ação; sobre os meios de prova, os requisitos da sentença, os recursos interponíveis. ${ }^{52}$ a coisa julgada. os pressupostos de admissibilidade da ação rescisória e da ação executiva (nulla executio sine titulo etc.). e sobre certos princípios inerentes ao processo de execução (prior in temipore, potior in iure, regras sobre a expropriação forçada etc.), certamente não são normas procedimentais, mas [...] normas processuais.

49 Evidente que se a União não legislar sobre processo (entenda-se: nio disciplinar at relação jurídica processual), Estados e Distrito Federal não poderão exercer sua competéncia plema (prevista no $\$ 3^{\circ}$ do art. 24) sobre procedimentos. Em sentido contrário: SUNDFELD, Carlos Ari. Competência Legislativa em Matéria de Processo e Procedimento. Revista dos Tribunatis. São Paulo, n. 657, p. 32-34. Para o autor. como há um dever de leggislar e sendo a legislação processual condição indispensável para a legislação de procedimentos, se a União não legisla subre processo. estão os Estados e o Distrito Federal autorizados a fazê-lo. Sem desprestigiar o entendimento do grande jurista é clara a Constituição: a competência plena é para legislar tão-somente sobre procedimentos. Em relação ao que sobeja da matéria processual (a relação jurídica) não há competência plena. em caso de omissão, aliás, nem suplementar: é privativa da Únião.

50 Excetuam-se. por força do referido inciso X, os juizidos de pequenas causas. Em relação a eles expressamente atribui-se alos Estados e ao Distrito Federal competência para legistar sobre toda matéria processual, limitando-se a União em editar as normas gerais.

51 A Constituição Federal e a legislação concorrente dos Estados e do Distrito Federal em matéria de procedimentos. Revista Forense. Rio de Janeiro, n. 324, p. 49-54.

52 Em uma das raras oportunidades em que se manifestou sobre a interpretição do referido art. 22. XI, o Supremo Tribunal Federal decidiu: "Mostra-se insubsistente, sob o ângulo constitucional, norma local que implique criação de recurso. Esta ocorre no ámbito da competencia para legislar sobre direito processual, não estando abrangida pela competência concorrente do inciso XI do artigo 24 da Constituição Federal". Ag. Reg. em Agravo de Instrumento n² 210.068-1, rel. Min. Marco Aurélio, j. 28.08.1998 
Em todas essas matérias, criam-se situações jurídicas, dá-se um ônus ao demandante e ao demandado, estabelece-se um estado de sujeição, disciplina-se, enfïm, a relação jurídica processual. Trata-se, portanto, de matéria processual que não se restringe à disciplina do procedimento. Continua o autor:

Entretanto, os modos, as formas como as citações e as instituições se farão, como certas provas se produzirão; as regras sobre os ritos de certos recursos e, particularmente, sobre os procedimentos propriamente ditos, ou seja, sobre a sequiência dos atos a ser praticados em casos comuns (ordinária. sumária ou executivamente) ou em casos especiais - certamente são normas tipicamente procedimentais, rituais.

Dificilmente a disciplina de uma dessas matérias não surtirá efeitos, ainda que indiretamente, na relação jurídica processual: visam diretamente ao procedimento, mas indiretamente atingem a relação. Como, no entanto, o objeto da regulamentação é a forma do encadeamento dos atos que compõe o processo e não a relação em si, parece correto considerar-se essas matérias exclusivamente procedimentais.

Conclui-se que processo é uma forma de exercício da democracia. Tem por finalidade garantir aos interessados o direito de participar do exercício do poder, ou seja, da tomada de decisão por um agente estatal. É composto de dois elementos estruturais, intrinsecamente ligados em prol dessa finalidade: uma sequiência de atos normativamente encadeados, em que cada ato é conseqüente do posterior e decorrente do anterior (procedimento) e uma relação jurídica entre os interessados e o Poder Público, representado pelo agente encarregado de proferir a decisão, relação complexa, abrangente de todas as situações que surjam durante o procedimento. A matéria processual compõe-se portanto da disciplina da relação jurídica e do procedimento. Por imposição dogmática, separam-se os assuntos diretamente ligados à disciplina do procedimento dos assuntos diretamente ligados à disciplina da relação jurídica, dando-se sentido às disposições constitucionais. Estas não impedem que entre processo e procedimento vislumbre-se uma relação de inclusão, desde que, a partir de uma interpretação sistemática, tome-se o inciso XI do art. 24 da Lei Maior como uma restrição ao inciso I de seu art. 22. Mantém-se, assim, plena afinidade entre as recentes concepções doutrinárias e o ordenamento jurídico brasileiro.

\section{O Processo Administrativo}

\subsection{Breve introdução}

Examinados os conceitos de processo e de procedimento à luz do Direito Processual Civil, resta saber se e em que medida são aplicáveis ao Direito Administrativo. Para tanto vários problemas precisam ser enfrentados: no que consiste o chamado procedimento administrativo; se existe, com rigor conceitual, um processo administrativo; a eventual diferença entre o procedimento administrativo e o processo administrativo. Todas essas questões precisam ser respondidas para a resolução do 
problema central: em que medida o capítulo anterior é aplicável ao campo do Direito Administrativo.

\subsection{O procedimento administrativo na teoria dos atos administrativos}

Célebre é a definição de ato adıninistrativo de Celso Antonio Bandeira de Mello: "declaração do Estado ou de quem lhe faça às vezes, no exercício de prerrogativas públicas, manifestada mediante providências jurídicas complementares da lei a título de lhe dar cumprimento, e sujeitas a controle de legitimidade por órgão jurisdicional"..$^{53}$ Inicialmente a doutrina do Direito Administrativo tratou do procedimento na teoria dos atos administrativos. No início do século passado era corrente a concepçcão s:Lstancialista do procedimento administrativo: todos os elementos da série careciam de autonomia, eram tão-só partes integrantes da decisão final, esta sim configuradora de um ato administrativo. ${ }^{54} \mathrm{O}$ procedimento era confundido. em certa medida, com o ato administrativo complexo. Essal concepção está absolutamente superada. $O$ ato complexo é uma manifestação unitária de vontade exteriorizada por dois ou mais órgãos administrativos, consubstanciando tão-somente um ato administrativo. O procedimento consiste num complexo de atos administrativos autônomos. Nessa segunda fase, superada a concepção substancialista. o procedimento foi tomado como requisito de validade de determinados atos administrativos.

Na clássica teoria dos atos administrativos de Celso Antonio Bandeira de Mello, dois são os elementos, as realidades intrínsecas do ato, os componentes dele: o conteúdo e a forma. Os elementos distinguem-se dos pressupostos, circunstâncias extrínsecas ao ato em si mesmo, condicionantes de sua existência e de sua validade. Dois são os pressupostos de existência ${ }^{55}$ do ato: objeto e a pertinência ao exercício da função administrativo. Cinco são os pressupostos de validade do ato: subjetivo. objetivo, teleológico, lógico e formalístico. O procedimento refere-se ao pressuposto objetivo de validade do ato administrativo.

Esclarecedor é o exemplo de Oswaldo Aranha Bandeira de Mello: o ato de provimento dos cargos públicos. Simplificando, há o ato administrativo da delibe-

53 Curso de Dirciro Administratioo. 13. ed. rev., atual e ampl. São Paulo: Matheiros. 2001. p. 343-344. O autor. porém. entende tratar-se de conceito e nào de definição.

54 Vide ENTERRÍA, García de; FERNÁNDEZ. Tomás-Ramón. Curso de Drecho Administrativo. 8. ed. Madri: Civitas, 2002. v. II, p. 448.

55 Critica-se a palavra "existência", apesar de funcionalmente importante na teoria. Se presentes seus elementos intrínsecos, formadores, necessários para sua constituição, não há como afirmar que, ausentes os pressupostos de existência, o ato inexiste. Poder-se-iat. para fugir dessa crítica, modificar a terminologia: elementos do ato jurídico e elementos do ato administrativo, ambos tomados como pressupostos da existência do ato administrativo. Sem os elementos do ato jurídico não há sequer ato, sem os elementos do ato administrativo, não há ato administrativo, mas há ato, em geral ilícito. O tema desborda os limites da exposição. Mantém-se, por isso, a terminologia da célebre doutrina de Celso Antonio. 
ração de abertura do concurso, seguido do ato administrativo da convocação dos candidatos por edital, após o ato administrativo da inscrição com acertamento dos títulos apresentados, ainda os atos administrativos do processamento das provas. classificação e o ato administrativo indicando os melhores classificados para nomeação. $\mathrm{O}$ ato final, de nomeação, completa-se com o de posse e entrada em exercício dos providos no cargo. O procedimento administrativo do concurso público, seguindo a lição de Oswaldo Aranha, engloba toda essa série de atos administrativos preparatórios do ato jurídico de nomeação. ${ }^{56}$ Percebe-se que cada ato possui sual autonomia e, portanto, exige a presença de elementos e pressupostos próprios, inclusive procedimentais. São atos jurídicos distintos que se sucedem e se ligam com o objetivo de produzir um ato jurídico final, o ato administrative conclusivo. $\mathrm{O}$ ato administrativo de convocação do candidato para realização das provas tem como rẹjuisito procedimental ou pressuposto objetivo de validade a correção dos atos anteriores. dentre eles, a aprovação da inscrição do candidato. Nessa medida, requisito procedimental e procedimento não são sinônimos. O procedimento é o conjunto de todos os requisitos procedimentais do ato administrativo final.

Daí o conhecido conceito de procedimento administrativo: "é uma sucessão itinerária e encadeada de attos administrativos tendendo todos a um resultado final e conclusivo". ${ }^{57}$ Há, no dizer de Oswaldo Aranhil, "plurallidade de atos jurídicos para se obter resultado último". ${ }^{5 \varnothing} \mathrm{O}$ procedimento se perfeiçoa quando efetivados todos os atos jurídicos necessários para validade do ato final. Em síntese, portanto, procedimento administrativo, na teoria dos atos administrativos. é o conjunto dos requisitos procedimentais do ato administrativo conclusivo.

\subsection{O procedimento administrativo e o exercício da função administrativa}

Uma nova fase do procedimento administrativo inicia-se com as considerações feitas por Merkel, apontado como o primeiro a dissociar o conceito de procedimento do processo judicial e eleví-lo à categoria geral do direito. ${ }^{59}$ Num lento progredir, sobretudo a partir da contribuição de Luhman. ${ }^{60}$ o procedimento deixa de ser considerado tão somente um tema da teoria dos atos administrativos e passa a ser referenciado como um importante capítulo do Direito Administrativo.

Os agentes públicos exercem função, ou seja, exercem o poder estatal no interesse dos cidadãos. ${ }^{61}$ Como agem em prol de terceiros, e não para o atendimento

56 Princípios Gerais de Direito Administrativo. Rio de Janeiro: Forense, 1968, v. I, p. 480.

57 BANDEIRA DE MELLO. Celso Antonio, 2001, p. 394.

58 BANDEIRA DE MELLO. Oswaldo Aranha, 1968, p. 478.

59 Nesse sentido BANDEIRA DE MELLO. Celso Antonio. 2001. p. 434. ENTERRIA: FERNÁNDES, 2002, p. 442 et seq.

60) Supra, item 2.4

61 Famoso é o conceito de função de Celso Antonio Bandeira de Mello: "existe funçĩo quando alguém está investido no dever de satisfazer dadas finalidades em prol do interesse de outrem, necessitando, para tanto, manejar os poderes requeridos para supri-las". Curso, op. cit., p. 32. 
de interesses próprios, evidente a necessidade de que os terceiros interessados não tenham tão-só a possibilidade de controlar o resultado dessa atividade. mas também seu exercício. O meio de controle do exercício da função estatal é o procedimento. Só através dele o cidadão tem como controlar, não o resultado do exercício do poder, mas o próprio exercício. Essas idéias só recentemente tornaram-se pacíficas. ${ }^{62}$ As três funções do estado resultam na produção de normas jurídicas; a legislativa. em gerais e abstratas; a judicial e administrativa em individuais e concretus. Não é necessário apenas controlar as normas produzidas, mas o modo de criação das normas, ponderou Carlos Ari Sundfeld. ${ }^{6.3}$ Somente o procedimento, meio de controle dessa criação, impede que o produto final, a norma editada, seja uma imposição autoritária.

A regra passou a ser a seguinte: nenhuma decisão estatal deve ser tomada fora de um procedimento, sob pena dessa decisão traduzir-se na imposição autoritária da vontade do agente que a emite. Essa regra tornou o procedimento um imperativo do exercício da função administrativo. O ato administrativo isolado, denominado ato administrativo solitário, passou a ser tomado como rara exceção. ${ }^{6+} \mathrm{O}$ procedimento passa, então, a ser responsável pela legitimidade do exercício da função administrativa.

\subsection{O uso da expressão procedimento administrativo}

Observa-se a não utilização, até aqui, da expressão processo administrativo. Prevalecia na doutrina o entendimento de que processo era termo reservado à atividade judicial. Nesse sentido manifestou-se expressamente José Frederico Marque:

Quando os atos se coordenam numa série sucessiva com um fim determinado, fala-se que há processo, se o movimento se realiza em função da atividade jurisdicional; se é uma atividade administrativa que se desenvolve, o que existe nessa série de atos, que se entrelaçam, é tão-só procedimento.

62 Daí o mérito, ao menos no direito pátrio, da prognóstica contribuição de Carlos Ari Sundfeld. O autor escreveu, antes da Constituição de 1988, magistral artigo intitulado "A importância do procedimento administrativo". Revista de Direito Público. Sío Paulo, n. 84, out.-dez. de 1987, Ano $\mathrm{XX}$, p. 64-74.

63 SUNDFELD, op. cit., p. 68-69.

64 Marcos Porta chega a negar a existência dos atos administrativos solitários: "Esses atos administrativos são considerados como solitários pela inexistência de qualquer processualidade jurídico-administrativa para sua existência ou validade. Todavia, admitir-se a existencia dos atos administrativos solitários vai de desencontro à própria importância que o direito reservou para a processualidade jurídico-administrativa, ou seja, o de servir como um instrumento de garantia dos administrados, entre outros. Por essa razão, não se admite sua existência". PORTA, 2003, p. 62. Um simples exemplo, sem desprestigiar o nobre jurista, evidencia o absurdo de sua posição. $O$ sinal luminoso de trânsito ao ficar vermelho corresponde a ordem de parar. Trata-se de ato administrativo. BANDEIRA DE MELLO. Celso Antonio. 2001. p. 338. Ato esse, evidentemente, solitário. 
Errôneo é, portanto, falar-se em processo administrativo, pois a expressão exata seria a de "procedimento administrativo" ${ }^{5}$

Essa orientação é enfaticamente sustentada pelo insigne Augustin Gordillo, justificando-a nesses termos:

Por outra parte. a tese ampla acercu da noção de processo é perigosal, pois sendo "processo" sinônimo usual de juízo, poderia levar a entender-se. como às vezes se tem sugerido, que não há violação da defesa em juízo se os direitos de um indivíduo são definitivamente resolvidos pela administração, sempre que esta haja ouvido o interessado. Mas, por certo, defesa em juízo é algo mais que ouvir o interessado. é também que haja um julgador imparcial e independente, qualidades essas que em nenhum caso a administração pode reunir plenamente. Por essa razão também é conveniente reservar o conceito de processo bem como o de juízo para o processo ou juízo estritamente judicial, evitando com esta terminologia possíveis confusões como as que acabam de ser recordadas. ${ }^{66}$

Carlos Ari Sundfeld, influenciado por Gordillo, também adota essa orientação, discriminando três argumentos para justificá-la. l) Costuma-se restringir o uso da expressão aos casos em que há controvérsia (procedimentos disciplinares, tributários), que mais se assemelham ao processo judicial. Tal atitude, se favorece a defesa do indivíduo nessas hipóteses, deixa-o indefeso nas demais. 2) A expressão sugere seja dado à Administração o poder de julgar definitivamente certas situações, desde que realize um procedimento semelhante ao judicial. 3) O Judiciário exerce função administrativa. É comum, ao exercerem essa função, os magistrados confundirem processo judicial com procedimento administrativo, mencionando-se o pitoresco caso de interposição de recurso extraordinário, em sede de processo administrativo disciplinar. ${ }^{67}$

Essa posição, ao menos no direito comparado, não está ultrapassada. É adotada por Eduardo García de Enterría e Tomás-Ramón Fernández. ${ }^{68}$ Interessa aqui apurar se tem pertinência no direito pátrio, partindo-se da premissa de que toda análise jurídica deve ter por base o direito posto. Os argumentos acima discriminados em prol da não utilização da expressão processo administrativo, a luz do direito brasileiro, não se sustentam. $O$ argumento de Frederico Marques já foi afastado no capítulo anterior: o conceito técnico-científico de processo é formado através de dois elementos, procedimento e relação jurídica processual. O exercício da função jurisdi-

65 MARQUES, 1997, p. 348-349.

66 GORDILlO, Augustín. Tratado de Derecho Administrativo: la defensa del usuario y del administrado. 1. ed. colombiana. Bogotá: Fundación de Derecho Administrativo, Bibliotecal Jurídica Dike, 1998, p. VIII-5, tradução nossa.

67 SUNDFELD, A importância do procedimento administrativ'o, p. 73.

68

ENTERRIA; FERNÁNDES, 2002, p. 442 et seq. 
cional não é seu elemento integrante. O argumento de Gordillo. correspondente ao segundo de Carlos Ari. é facilmente afastado no Brasil por força da expressa previsão constitucional do princípio do não afastamento do controle judiciário ${ }^{(2)}$ ou do direito fundamental à ação jurisdicional (art. 5\%. XXV. da Constituição). O riscoo temido pelos inolvidáveis juristas é, nesses termos, impensável no ordenamento juridico brasileiro. O primeiro argumento de Carlos Ari também não prospera: a restrição da expressão processo administrativo aos casos em que há controvérsia consiste em erro comum de parte da doutrina, conforme examinado a seguir. O último argumento, suscitado por Carlos Ari, também não merece atenção: dar tal importância à ignorância e ao equívoco de alguns importa em total inversão de valores

\subsection{O uso da expressão processo administrativo}

A doutrina exposta nunca foi pacítica, muitos utilizaram e utilizam a expressão processo administrativo. Entre aqueles que a adotam, todavia, existe um evidente emaranhamento conceitual. Marcelo Cátano não via óbices na utilização do termo processo na seara do Direito Administrativo. Vislumbrava dois tipos de processos: o contencioso, em que a decisão final é jurisdicional; e o gracioso, em que a decisão final é administrativa. O denominado processo contencioso existe nos Estados em que viggora o sistema de jurisdição dual: em determinas catusàs afetas à Administração a jurisdição é por esta exercida. Esse processo. por evidente. é praticamente idéntico ao judicial, alterando-se apenas o órgão dele encarregado. Nos países de jurisdição una, tais como o Brasil, não existe contencioso administrativo. ${ }^{70}$ Estals são as palavras do célebre professor da Faculdade de Direito de Lisboa:

Mesmo na doutrina estrangeira, onde o processo gracioso tem sido mais estudado, os administrativistas temem invadir a zona da ciência processual e pretendem criar a par do processo propriamente dito, que seria o contencioso, o termo procedimento reservado para designar a simples técnica de funcionamento da máquina administrativa. Naio vemos porém qualquer vantagem em criar um termo como procedimento ou processamento quando na própria ordem judicial existem os processsos de jurisdição voluntária que são processos graciosos (Cód. de Processo Civil. arts. 1 t09 e segs.) e pouco se afastam dos seus congêneres administrativos. ${ }^{71}$

69 Impropriamente chamado princípio da inafastabilidade do controle judiciário. A palavra "inafastabilidade" não encontra registro no vernáculo.

70 Como esta exposição toma por objeto de análise o direito brasilciro, a utilização do termo processo administrativo, ao longo do texto. reporta-se alo processo gracioso. A utilização, aqui, da expressão processo administrativo só se refere ao contencioso administrativo caso haja expressa referência nesse sentido.

71 CAETANO. Marcelo. Manual de Direito Administrativo. 10. ed.. 6. reimpr. Coimbra: Almedina, 1999, p. 1292. grifo do autor. O dispositivo mencionado. do Código de Processo Civil português. corresponde ao 1.103 do Código brasileiro. 
O conceito do autor, no entanto, não parrece correto. Tuma o termo processo no sentido de " sucessão ordenada de formalidades preestabelecidas tendente à formação ou à execução de uma vontade funcional”. Esse é o conceito científico de procedimento, não de processo. ${ }^{72}$

No Brasil, antes da Constituição de 1988. Hely Lopes Meirelles concebia processo como o "conjunto de atos coordenados para a obtenção de decisão sobre uma controvérsia no âmbito judicial ou administrativo". "7.3 Processo, para ele, possuiria dois elementos estruturais: o procedimento, o modo de realizaçio do processo, seu rito, e a controvérsia. Não é possível, dizia, processo sem procedimento, mas tranqüilamente possível procedimento sem controvérsia. Por força da prática administrativa, ponderava, todos os procedimentos. no entanto. são chamados de processos. Daí propunha a classificaf̧ão: processos administratios propriamente ditos. que encerram um litígio entre a Administração e o administrado. e processus adminis. trativos impropriamente ditos, simples expedientes que tramitam pelos órgãos administrativos, sem qualquer controvérsia entre os interessados. Essa doutrina também não é aqui acatada. A controvérsia não é elemento essencial do conceito científïco de processo. ${ }^{74}$

Com a Constituição de 1988 o tema tomou novos ares. O constituinte nấo deixou dúvidas de que o termo processo não se restringe ao judicial. O processo administrativo é mencionado em diversos dispositivos do texto constitucional: art. 5"., inciso

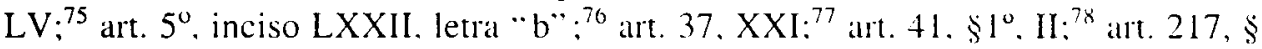
$2^{\circ} ;^{79}$ art. 247, parágrafo único: $:^{80}$ ant. 26, $\$ 2^{\circ}$, do ADCT. ${ }^{81}$ O dircito positivo, atssim,

72 Supra, 2.3. O assunto será retomado al seguir (infra, item 3.6).

73 MEIRELLES, Hely Lopss. Direito Administratio Brasileiro. 8. ed. atual. São Paulo: Revista dos Tribunais. 1981, p. $656 \mathrm{et} \mathrm{seq.}$

74 Supra, 2.4. O assunto é retomado adiante (infra. itèn 3.8).

75 "Aos litigantes, em processo judicial ou administrativo e alos acusados em geral são assegurados o contraditório e ampla detesal, com os meios e recursos a cla inerentes." (grifou-se).

76 "Conceder-se-á habeas data: b) para a retificaçaio de dados, quando não se prefïra fazề-lo por processo sigiloso, judicial ou administrativo." (grifou-se).

77 "Ressalvados os casos especiticados na legislaçău. as ubras, serviços. complats e alienaçóes serão contratados mediante processo de licitação pública que assegure iģualdade de condições a todos os concorrentes, com cláusulas que estabeleçam obrigaçōes de pagamento, mantidas as condições efetivas da proposta. nos termos da lei. o qual somente permitirá as exigências de qualificação técnica e econômica indispensáveis à garatnia do cumprimento dás obrigações." (grifou-se).

78 "O servidor público estável só perderá o cargo: mediante processo administrativo em que Ihe seja assegurada impla defesal." (gritou-se).

79 "A justiça desportiva terá o prazo máximo de sessenta dias, contados da instauraçăo do processo, para proferir decisão final." (grifou-se).

80 "Na hipótese de insuficiência de desempenho, a perda do cargo somente ocorrerá mediante processo administratio em que the sejam assegurados o contraditório e a ampla defesa." (grifouse).

81 "Apurada irregularidade, o Congresso Nacional proporá ao Poder Executivo a declaração de nulidade do ato e encaminhará o processo ao Ministério Público Federal, que formalizará. no prazo de sessenta dias, a ação cabível." (grifou-se). 
obrigou, ao menos no Brasil, uma revisão por parte da doutrina majoritária. A partir da promulgação do texto, por imposição constitucional. processo não é mais um instituto apenas da função jurisdicional. Esse é chamado por Sérgio Ferraz e Adilson Abreu Dallari de critério normativo para adoção da expressão." Nessa nova fase ninguém mais, na doutrina nacional, nega a aplicação do termo ao Direito Administrativo. Cada doutrinador, no entanto. passou a usá-lo com um significado distinto, em completa falta de sintonia conceitual.

Sérgio Ferraz e Adilson Abreu Dallari afirmam existir duals realidades abarcadas na palavra processo: a primeira é "uma realidade maior. o todo, panoramicamente identificado num conjunto, teleologicamente concebido, que parte de uma provocação ou requerimento e, por consequiência inelutável, caminha, mediante a prática de atos instrumentais, para a produção do resultado inevitável, qual seja, a decisão" : a segunda é "uma realidade atomizada, concretizada no caminho que vai do início ao fïm do processo, isto é. exatamente nat série de atos. encadeados lógica e juridicamente" ${ }^{8 t}$ A realidade maior é o processo, a menor é o procedimento. A posição dos autores também não pode ser aceita: a realidade atomizada, ou seja, os atos individualmente considerados, são os chamados requisitos procedimentais e não o procedimento. ${ }^{85}$ Este é o conjunto, é toda série de atos, encadeamento unido para a produção do ato final, portanto, teleologicamente concebido. As realidades maior e a menor, ao menos da forma que foram conceituadas pelos ilustres juristas, consistem

82 FERRAZ; DALLARI, 2001, p. 35 . O critério normativo tem uma dimensio muito maior do que a dada pelos juristas: a utilizaçăo de uma palavra pelo constituinte tem sérias consequências. Trata-se de importante tópico da interpretação constitucional. A inserção de uma palas ra ou expressĩo no texto constitucional sem que conste do texto a definição de seu conteúdo exig̨e o seguinte raciocínio: 1) uma palavra ou expressĩo não é inserida no texto constitucional com conteúdo vazio (palavras são signos é, portanto, sempre se referem a algo), a palavra ou expressão tra\% consigo un determinado significado que é constitucionalizado: 2) Se a palavra ou expressão constar da linguagem do povo, deve ser tomada pelo seu significado popular. Ex.: casa. 3) Se a palavra ou expressão não for própria da linguagem popular, mas sim da linguagem técnica, deve ser tomada pelo significado que os técnicos, em geral, atribuíam a essa palavra quando da promulgação da Constituição. Esse significado se constitucionaliza. 4) Se a palavra ou expressāo for técnica, mals não possuir um significado técnico corrente no momento da promulgaçăo da Constituição, deve ser tomada como um conceito indeterminado, cujo significado deve ser atribuído pela doutrina ou pelo legislador. 5) No primeiro e no segundo casos, a palavra ou expressão possui. sempre. um núcleo essencial que não pode ser alterado sem reforma constitucional. O significado constitucionalizado pode ser modificado sem reforma constitucional desde que se respeite esse núcleo essencial. Feitas essas consideraçōes pondera-se: se por um lado não existia ná doutrina brasileira do direito administrativo um uso corrente da expressĩo processo administrativo, por outro não há como negar a existência de significado consolidado da palavra processo na doutrina do processo civil. A conclusão fixada no capítulo anterior já era majoritária quando da promulgação da Lei Maior. Por força disso, o conceito corrente de processo constitucionalizou-se com a utilização da expressão pelo constituinte.

83 FERRAZ: DALLARI, 2001, p. 32.

84 FERRAZ: DALLARI, loc. cit.

85 Supra, 3.2. 
numa só realidade e referem-se, ambas, ao procedimento. Seria irretocável a doutrina se a realidade maior fosse caracterizada pela soma do procedimento com a relação jurídica. Não foi isso, no entanto, o que afïmaram.

Diógenes Gasparini acata, hoje. integralmente as lições pretéritas de Hely Lopes Meirelles, ${ }^{86}$ merecendo, assim. a crítica dantes formulada para atcuela posição. Diogo de Figueiredo Moreira Neto menciona conceito similar ao de Sérgio Ferraz e Adilson Abreu Dallari, merecendo, também, a crítica a pouco formulada. ${ }^{87}$

Para Maria Sylvia Zanella Di Pietro o processo existe como instrumento indispensável para o exercício da função administrativa. Cada vez que a Administração for tomar uma decisão, executar uma obra. celebrar um contrato. editar um comportamento, diz a autora, o ato final é sempre precedido de uma série de atos materiais ou jurídicos, ou seja, há processo. Procedimento é o conjunto de formalidades que devem ser observadas para a prática de certos atos administrativos. equivale a rito, a forma de proceder. E conclui: quando a lei não estabelecer procedimentos a serem observados pela administração, haverá processo, mas ela estará livre para escolher a forma de seu agir; em outras hipóteses, quando a lei estabelecer uma sucessão de atos preparatórios que devam obrigatoriamente preceder a prática de um ato final, haverá, além do processo, o procedimento. ${ }^{x 8}$ A doutrina é muito interessante, mas também não pode ser acatada. Em certo ponto aproxima-se das modernas teorias sobre o procedimento, que o exigem para legitimação da ação administrativa. Esta só é legitima se existir aquele. Ocorre que. conceitualmente. o conceito de processo enunciado pela autora em nada difere do conceito de procedimento. Inviável, do ponto de vista científico, tomar processo como gênero abrangente de procedimento regrado e procedimento não regrado e procedimento como sinônimo de procedimento regrado, como faz a autora.

Carlos Ari Sundfeld, em recente artigo doutrinário, deixa expresso que, no seu entender, tanto faz usar o termo processo ou procedimento. Trata-se de questão puramente terminológica. Di q que, segundo alguns, é importante usar o termo processo para afirmar com ênfase a incidência nat esfera administrativa dos grandes princípios processuais. Concorda com essa colocação. mas categoricamente afirma

86 GASPARINI. Diógenes. Direilo Administrativo. 9. ed. rev. e atual. São Paulo: Saraiva. 2004, p. 829.

87 Eis o conceito do autor: "o processo se exterioriza pelo procedimemo, como encadeamento de atos caracterizados pelo fato de que o ato antecedente é condicionante do consequente, convergindo todos para atingir um fim comum, guardando. embora, cada um deles, sua autonomia, para conformar um processo no seu todo". MOREIRA NETO, Diogo Figueiredo Moreira. Curso de Direito Administratio. 13. ed. rev., ampl. e atual. Rio de Janeiro: Forense, 2003, p. 156. Ora, o que diferencia o processo do procedimento não é alquele ser o todo. mas referir-se também à relaţ̃̃o jurídica. O procedimento, insiste-se, não se confunde com os atos individuatizados, também se refere ao conjunto e também é dotado de unidade telcológica.

88 DI PIETRO, Maria Sylvia Zanella. Direino Administratio. 11. ed. São Paulo: Allas. 1999. p. 483. 
não ver no uso da expressão maior efeito prático. ${ }^{\mathrm{k})}$ A posição é também inadmissível. Se processo e procedimento administrativo fossem cientificamente expressóes sinônimas o uso de uma ou outra terminologia seria absolutamente irrelevante. Ocorre que, conforme defendido aqui, há diferença científica entre as expressōes e. por força disso, não se trata de pura e simples escolha terminológica do cientista. Não se concorda também com a utilização do termo processo para se enfatizar a incidência de princípios do processo jurisdicional. ${ }^{\text {y }}$

A posição de Carlos Ari é adotada. em certa medida. pelo fúlgido Celso Antonio Banderia de Mello. Este afirma que a nomenclatura mais comum entre nús é a de procedimento, reservando-se. no Brasil, o nomen jaris proceiso para os casos contenciosos, a serem resolvidos por um "julgamento administrativo". Após. pondera que não é o caso de armar-se um "cavalo de batalha" en torno de róulos. No entanto. registra crer que a terminologia correta é processo, sendo procedimento a "modalidade ritual de cada processo". Por fïm. prognostitica que entre a tradição e a recente terminologia legal deva prevalecer a segunda. As kícidas consideraçōes do respeitado administrativista não são acatadas nesta exposição. A Ciência busca sempre uma linguagem dotada de extremada precisão. livre de ambigüidades. $\mathrm{O}$ uso desses rótulos, caso fixados conceitos científicos diferentes, não é ditado apenas pela simples menção no direito positivo ou pela tradição. mas pela Ciência." Além disso. como afirmado anteriormente. o significado corrente de processo constitucionalizou-se com a utilização do termo pelo constituinte. ${ }^{9 ?}$

Por fïm, digna de nota é a doutrina da ínclita Lúcia Valle Figueiredo. A autora, numa tentativa de sistematização do assunto, toma o lermo processo (em sentido amplo) como gênero que compreende três classes: 1) o procedimento considerado como forma de atuação da Administração Pública: 2) o procedimento considerado como uma sequiência de atos; 3 ) e o processo em sentido estrito. A primeira categoria de processo em sentido amplo consiste, segundo a autora, na primeira acepção de procedimento, conceituado como "conjunto de formalidades necessárias para emanação do ato administrativo". Essa cattegoria sempre esta presente. negando a autora a possibilidade de atos implícitos." A segunda categoria corresponde a segunda

89 Processo e procedimento aldministrativo no Brasil. In ST NDFEI.D Cirlo Ari (courd.): ML:ÑOZ. Guillermo Andrés (courd.). As Leis de Processo Administranos: Lei Federal $9.78+199$ e Lei Paulista 10.177/98. São Paulo: Malheiros. 2000. p. 19.

$90 \mathrm{O}$ assunto é melhor examinado a seguir (infra. item 4.0).

91 Observa-se. contudo, que a Ciência do Direito, tendo por objeto de estudo o direito positivo, não pode chegar a conclusões incompatíveis com este, sub pena de trair seus propósito. Não é al simples menção da expressão no direito positivo que ditia seu uso. mals at menção intlui nas conclusôes científicas na medida em que estats não possam desprezá-lat.

92 Vide o exposto na nota 82, supra.

93 Atos administrativos implícitos sĩo conceituados por Vicente Escuin Palop como "ajueles comportamentos dos quais se desprende uma declaração de vontade de um órgão administrativo sem seguir o correspondente procedimentu". El acto administratio implicite. 1. ed. Madri: Civitats, 1999, p.13. O atutor cita como exemplo a afetação a a desafetação no domínio público estatal. Prefere-se, no entanto, conceitui-los como atos administrativos que sĩo expedidos sem formaliza- 
acepção da palavra procedimento: seqüência de atos administrativos, lodus tendentes a um ato final, servindo-lhe de suporte de validade. Essá categoria também esta sempre presente, negando a autora a possibilidade de atos solitários. ${ }^{y 4}$ A terceira categoria é o processo administrativo em sentido estrito: existe quando há controvéria (litígio) ou "acusaçōes em geral". ".5

Essa complexa sistematização é aqui também integralmente afastada. A primeira categoria mencionada pela autora nada tem a ver com procedimento. Trata-se dos chamados requisitos procedimentais do ato administrativo. $\mathrm{O}$ ato isolado do procedimento não é o procedimento. mas um requisito procedimental dos atos subsequientes. ${ }^{96} \mathrm{~A}$ segunda categoria consiste, de fato, no procedimento administrativo. contudo não há como tomá-lo como espécie do processo administrativo. A relação entre processo e procedimento é de inclusão. não no sentido de gênero-espécie, mas sim no sentido de continente-conteúdo. Procedimento não é uma espécie de processo, pois faz parte de sua própria estrutura conceitual. ${ }^{97}$ Por fim. já se afirmou diversas vezes: a controvérsia não é parte integrante clo conceito de processo."

Esse sucinto panorama é suficiente para demonstrar a falta de uniformidade na utilização das expressões processo e procedimento administrativos. Descreveu-se, ainda que rapidamente, a evolução da utilização doutrinária das expressões processo e procedimento administrativos pela doutrina brasileira do Direito Administrativo. Antecipou-se a maior ou menor discordância com todas as posiçôes doutrinárias até aqui mencionadas. Todas as doutrinas expostas neste catpítulo, sem exceção, foram de um modo ou de outro, afastadas. Apontou-se, laconicamente, o erro de cada uma delas. O passo seguinte é a exposição da teoria ora defendida.

\subsection{Os conceitos cientificos de processo e procedimento administrativos}

Pelo que até aqui se expôs, já fícou claro que processo e procedimento são institutos da Teoria Geral do Direito, decorrentes do princípio democrático. O exercício do poder consiste na tomada de uma decisão. O ato de decidir, por sua vez, consiste em uma declaração linguística de vontade: decidir é escolher uma dentre

ção, ou seja, sem a adoção de qualquer requisito procedimental. por isso chamados implicitos. Apesar de violadores dos pressupostos objetivos e tormalísticos. ainda assim. sio considerados válidos. O exemplo é comum: a Administraçũo realizal obra públical sem empréender a desapropritit ção. Com a realização da obra, o bem passal a estal afeliddo au domínio público. Trata-se de declaração de vontade da Administração, portanto. de ato administrativo. Válido: gera a afietação. Implícito: praticado sem obediência aos pressupostos objetivos a formalísticos de vallidade. Discorda-se, assim. da autora: existem, apesar de raríssimos. atos administrativos implícitos.

94 O assunto foi examinado na nota 64, supra.

95 FIGUEIREDO, Lúciat Valle. Curso de Direito Administrativo. 6. ed. rev.. atuall. e ampl. São Paulo: Malheiros. 2003, p. 416 et seq.

96 Vide supra 3.2.

97 Vide supra 2.6.

98 Vide supra 2.4. 
duas ou mais alternativas incompativeis; é, assim, escolher. A decisão é, nesse sentido. um ato de vontade declarada, tomado sempre pelo agente estatal. ${ }^{99}$ É o agente estatal quem exerce o poder público, proferindo decisões. ou seja. atos de vontade declarada. Percebe-se o seguinte: quanto maior a liberdade para proferimento desse ato, menor será o peso do princípio democrático. Num regime absolutamente totalitário o agente estatal tem total liberdade para exercer o poder: a decisão a ser tomada é fruto de sua livre vontade, ele exerce o poder como quer, da forma que quer e para os fins que deseja. Nesse regime o agente público tende a não exercer sua função: ${ }^{100}$ com a total liberdade que possui para decidir, tende a exercer o poder em prol de seu interesse pessoal e não em prol do interesse dos cidadãos.

Num regime democrático essa liberdade é acentuadamente limitada. O agente exerce função, age sempre en prol do interesse dos cidadãos. Sua decisão não é fruto tão-somente de sua vontade. O elemento volitivo existe. mas é abalado por uma série de fatores. O principal deles: garante-se aos diretamente interessados na decisão a ser tomada a possibilidade de intervirem no " processo" (em sentido vulgar) de decisão do agente. O "processo de decisão" do ser humano é efeluado por cada um, todos os dias. milhares de vezes. Trata-se, em regla, de um processo puramente psicológico de sopeso dats alternativats. Paral o agente estatal isso se torna muito mais complexo por força da necessidade de se garantir aos diretamente interessados na decisão a ser tomada que interfiram no seu processo íntimo de escolha das alternativas. Só existe uma torma de se garantir aos diretamente interessados a possibilidade de interferirem no processo psicológico de decisão do agente encarregado de tomá-la: essa forma é o processo (em sentido jurídico).

Processo, portanto, é uma categoria geral do direito. O legislador. o juiz. o administrador ao exercerem o poder público, tomatm decisões. Daí o processo legislativo, judicial e administrativo. À Ciência do Direito. por conseqüência, impõe-se o dever de erigir o conceito geral de processo. aplicável a todas as searas jurídicas. Como já afirmado, foram os estudiosos do processo civil os que mais debateram os contornos estruturais do processo. Ora, abstraindo as características peculiares do processo jurisdicional (a seguir examinadas), sua diferença específica que o faz jurisdicional, obtém-se as características genéricas, aplicáveis a todos os processos, obtém-se o conceito científico de processo. E foi exatamente isso o que se fez no primeiro capítulo: analisou-se, a partir das contribuições da doutrina do Processo Civil, o instituto do processo, abstraindo-se suas características. sua diferença específica, que o fazem jurisdicional.

Obteve-se um conceito que, por ser compatível com o direito positivo e obediente a sólidas premissas. é aqui considerado científico. Afirmou-se haver efeitos

99 "En suma. a vontade e a ação do Estado (manifestada por seus órgãos, repita-se) são constituídas na e pela vontade e ação dos agentes: ou seja: Estado e órgãos que o compõem se exprimem através dos agentes. nat medida em que ditas pessoals físicas atuam nesta posição de vé́culos de expressão do Estado". E a lição insuperável de Celso Antonio Bandeira de Mello (2001, p. 106).

100 Cujo conceito foi enunciado na nota 61 supra. 
jurídicos de duas espécies: uns decorrentes da prática de um único ato, chamado ato instantâneo; outros decorrentes da prática de vários atos. em que vários atos precisem ser praticados para que surja o ato final, gerador de efeitos jurídicos. Esse é o conceito de procedimento: série de atos legalmente ordenada. de modo que cada ato é antecedente do posterior e consequiente do anterior e todos estão teleologicamente ligados para obtenção do ato final (a decisão. concretização do exercício do poder estatal).

Afirmou-se que a Ciência Jurídica tem como premissa não contradizer o direito positivo, sob pena de contrariar seus propósitos. Conclui-se que processo e procedimento, por imposição dogmática, são conceitos distintos, nem por isso excludentes. Há entre eles uma relação de inclusão, mais precisamente, de continente-conteúdo. Processo é procedimento. mas se diferencia dele por ser algo a mais: é o conjunto de processo e relação jurídica processual. Esta é uma relação unitária, abrangente de todas as situações jurídicas que surjam entre o diretamente interessado na decisão e o Poder público, representado pelo agente encarregado de tomá-la. O sistema jurídico, para garantir o desiderato do processo, institui. em favor dos interessados na decisão, determinadas situações jurídicas: ônus, poderes, faculdades. deveres, sujeições. Essa relação decorre do conjunto das situações que surjam durante o procedimento, entre os interessados e o Estado. Processo, pois, é uma série ordenada de atos destinada a prolação do ato final, ato conclusivo consistente numa decisão (concretização do exercício do poder estatal). e uma relação jurídica entre o Poder Público e os diretamente interessados na decisão, de modo que estes tenham instituída, a seu favor, uma série de situações jurídicas que lhes permitam influenciar no processo psicológico de escolha das alternativas próprio do ato de decidir.

Esses conceitos de procedimento e processo, desenvolvidos a partir das formulações enunciadas no primeiro capítulo, são inteiramente aplicáveis ao Direito Administrativo. Procedimento administrativo é uma série de atos administrativos autônomos, ordenados de modo que cada ato seja condição de validade do ato anterior, teleologicamente vinculados para a expedição do ato administrativo conclusivo, consistente numa decisão da Administração. Processo Administrativo consiste num procedimento administrativo em que vigore uma relação jurídica entre a Administração e os interessados diretos na tomada de decisão. Nessa relação jurídica há uma série de situações jurídicas instituídas em favor desses administrados, garantido-lhes a possibilidade de influenciar na tomada de decisão.

A adoção dos termos processo e procedimento administrativo impõe-se por dois motivos: o primeiro é o referido critério normativo (supra. 3.5); o segundo é o critério científico. ${ }^{101}$ A escolha arbitrária entre esses termos assemelha-se a escolher entre antijuridicidade e crime. O crime consiste na antijuridicidade, mas não se confunde

101 Despreza-se assim o denominado critério ideológico. Para Adilson Abreu Dallari e Sérgio Ferraz a utilização da expressão processo administrativo deve prevalecer, inclusive por um motivo ideológico: "o constituinte teria outorgado ao processo administrativo a mesmal índole $c$ alcance do processo judiciall". (2001, p. 35). Afirmação que, com todo respeito, é aqui repudiada, conforme a seguir exposto (infra. item 4.6). 
com ela. ${ }^{102}$ Processo e procedimento administrativos são dois institutos decorrentes da Teoria Geral do Direito que não podem ser ignorados ou desconsiderados pela doutrina. Nenhum dos autores examinados, adotou-os. Todos se afistaram deles, em maior ou menor medida.

Marcos Porta, propositadamente não citado no item anterior, foi quem mais se aproximou desses conceitos. Em sua recente Dissertação de Mestrado, defendida na Pontifícia Universidade Católica de São Paulo, o ilustre magistrado concluiu: "Portanto, o processo administrativo pode ser conceituado como uma relação jurídica processual-administrativa. autônoma. que está a serviço do Direito Administrativo, edificado na idéia de Estado Democrático de Direito". "E, Ediante: "O processo administrativo também pode ser conceituado como procedimento. Nesse sentido, configura-se como pressuposto objetivo para a emanação de atos administrativos e como rito procedimental, entendido como uma sequêencia de atos administrativos tendentes a um ato final". ${ }^{04}$ Discorda-se, contudo, do autor: influenciado por Lúcia Valle Figueiredo confunde procedimento, conjunto de atos, com pressuposto objetivo de validade, ato individualmente considerado. ${ }^{105}$ Além disso: dá dois conceitos para processo: relação e procedimento. Daí a discordância. não se pode ora conceituar o processo como relação jurídica, ora conceituá-lo como procedimento, pois. processo administrativo é procedimento e relação jurídica, no exato sentido de soma, adição, junção.

Fixaram-se aqui os conceitos de processo e procedimento administrativos. Em termos genéricos, conceito é " a forma intelectual que exprime o objeto do conhecimento" ${ }^{106}$ Tem por conteúdo a expressão das notas e características que definem esse objeto. ${ }^{107} \mathrm{O}$ entendimento do conceito exige o exame de suas propriedades: a compreensão, diversas qualidades ou atributos que ele conota, e a extensão, conjunto de seres que o conceito denota. ${ }^{108}$ Conseqüentemente, para a apreensão dos dois

102 Existem várias correntes sobre o conceito analítico de crime. As principais: fato típico e antijurídico; fato típico, antijurídico e culpável: fato típico, antijurídico, culpável e punível. Sobre as principais correntes, por todos MONTEIRO DE BARROS. Flavio Augusto. Direito Penal: parte geral. 2. ed. rev.. atual. e ampl. Sĩo Paulo: Saraiva, 2001, 1. 1. p. 103-104. A primeira corrente é aqui adotada apenas para facilitar a comparação. Para os que consideram o crime como fato típico e antijurídico é. evidentemente. incorreto afirmar que crime é sinônimo de fato antijurídico. Crime é fato antijurídico. mas não somente isso: é também típico. O uso dos termos antijurídico e típico não decorre tão-somente de eventual menção no direito positivo (critério normativo), decorre da contribuição da Ciência do Direito, pois são termos cientíticos. A escolha dessa terminologia é, em certo sentido, vinculada. Isso é exatamente o que ocorre em relação aos termos processo e procedimento.

103 PORTA, 2003, p. 76.

104 Ibid., p. 77.

105 Supra. 3.5.

106 ALVES. Alaôr Caffé. Lógica: pensameno formal e argamentação. 2. ed São Paulo: Quartier Latin, 2002, p. 168.

107 Ibid., p. 185.

108 Aluôr Caffé Alves define compreensão como "conjunto dos elementos (notas) que formam a 
institutos, processo e procedimento, não basta a conceituação. É necessário aprofundar o exame, assinalando suas características e identificando as realidades às quais se aplicam.

\subsection{A dupla finalidade do processo administrativo}

A Lei Federal brasileira de Processo Administrativo (Lei 9.784/99), na elogiável redação do art. $1^{\circ}$, consignou expressamente os dois objetivos do processo administrativo: "Esta lei estabelece normas básicas sobre o processo administrativo no âmbito da Administração Federal direta e indireta, visando, em especial. a proteção dos direitos dos administrados e ao melhor cumprimento dos fins da Administração". A Administração precisa tomar uma decisão e o meio de fazê-lo é o processo administrativo. É este, portanto, o meio que possibilita a atuação administrativa. Por outro lado, os cidadãos têm o direito de influir na decisão a ser tomada pela Administração. As palavras de Eduardo García de Enterría e Tomás-Ramón Fernández evidenciam essa dualidade:

O procedimento administrativo, se bem constitui uma garantia dos direitos dos administrados, não esgota nele sua função, que é, também. e principalmente, a de assegurar a pronta e eficaz satisfação do interesse geral mediante a adoção de medidas e decisões necessárias pelos órgãos da Administração, intérpretes desse interesse e, ao mesmo tempo, parte do procedimento e árbitro dele mesmo. ${ }^{109}$

Marcelo Caetano também notou essa duplicidade teleológica e explicou, em lapidares palavras, a tensão que entre elas existe:

O processo administrativo é. pois, não só o instrumento adequado da ação jurídica da Administração pública mas também uma garantia dada aos particulares de que as pretensões confiadas aos órgãos administrativos serão examinadas em termos de permitir soluções legalmente corretas.

Se por um lado estas duas finalidades do processo administrativo se completam, por outro chocam-se. Como nota Lopez Rodó, "o interesse público exige que se adopte uma forma simples e rápida no processamento dos assuntos, o bastante para evitar a anarquia interna da Administração e a ilegalidade de seus actos, ao passo que o interesse dos particulares pede que

natureza do ser representado pelo conceito" ou, em outras palavras, "é o conteúdo de um conceito; e o conjunto de elementos, de notus ou caracteres que o conceito contém". (2002, p. 203). Define extensão como "conjunto de elementos (indivíduos) aos quais o conceito convém" ou. em outras palavras "é o conjunto de indivíduos que possuem a mesma compreensāo". (2002, p. 204).

109 ENTERRIA: FERNÁNDES, 2002, p. 443, tradução nossal. 
a actividade administrativa esteja submetida a um processo rigoroso, que deixe manietada a Administração impedindo-a de avassalar os seus administrados". 10

De um lado, o processo é o meio de exercício da função administrativa. A Lei impõe à Administração uma colossal série de deveres. Como por regra geral só pode atuar mediante processo, esses deveres são cumpridos através dele. Daí um dos fins do processo: possibilitar, da melhor forma possivel, o exercício da função administrativa, ou seja, que ela cumpra, da melhor maneira, os seus deveres. De outro, o processo é o meio pelo qual o cidadão influi na atividade administrativa. É pelo processo que o cidadão participa da atuação administrativa e influi na tomada de suas dccisões. É, nesse sentido, um direito político do cidadão.

Esses dois fins traduzem-se em dois princípios: o principio democrático e o princípio da eficiência." Princípios, conforme as novas concepções vigorantes, estão em constante colisão: diante do caso concreto. mediante a ponderação dos interesses envolvidos, apura-se o peso de cada princípio e a medida de sua incidência. ${ }^{112}$

\subsection{As espécies de processos administrativos}

Velha e eternamente correta é a lição de que classificações não são certas ou erradas, são adequadas ou inadequadas a determinado objetivo. ${ }^{113}$ A exposição tem

110 CAETANO, 1999, p. 1290-1291.

111 Princípio da eficiência. tornado expresso com a Emenda Constitucional $n^{\circ} 19$, traduz bem a segunda finalidade mencionadat. No antigo conceito de Hely Lopes Meirelles; "dever de eficiência é o que se impõe a todo agente público de realizar suas atribuiçōes com presteza, perfeição e rendimento funcional". É o mais moderno princípio da função administrativa, que já não se contenta em ser desempenhada apenas com legalidade, exigindo resultados positivos para o serviço público e satisfatório atendimento das necessidades da comunidade e de seus membros". (1981. p. 79). Abrange: a produtividade do exercente do cargo ou função. a perfeiçĩo do trabalho e a sua adequaçióo técnica alos fins visados peta Administração.

112 O tema dos princípios jurídicos sofreu extraordinária evolução nas últimas décadas, tema fértil. extrapolat os estreitus limites desta exposição. Sobre o conceito de princípios jurídicos imprescinJivel at leitura de ALEXY. Rubert. Teoria de los Derechos Fundamentales. Traduçä́o de Ernesto Garzón Valdés. 1. ed. 2. reimpr. Madri: Centro de Estudios Políticos Y Constitucionales, 2002, p. 51. Titulo original: Theorie Der Grundrechte: DWORKI. Ronald. Le'vando os Direitos à Sério. 1. ed. São Paulo: Martins Fontes, 2002. Título original: Taking Rights Seriously e de ÁVILA, Humberto. Teoria dos Princípios: da definição à aplicação dos princípios jurídicos. São Paulo: Malheiros, 2003. Sobre a colisão entre princípios recomenda-se a leitura de SARMENTO, Daniel. A Ponderação de Interesses na Constituição Federal. $1^{\text {a }}$ ed., $2^{2}$ tir., Rio de Janeiro: Lumen Juris, 2002 e STEINMETZ. Wilson Antônio. Colisão de Direitos Fundamentais e Principio da Proporcionalidade. Porto Alegre: Livraria do Advogado, 2001.

113 A lição é do venerável Genaro R. Carrió: " as classificaçōes não são nem verdadeiras nem falsas, são úteis ou inúteis; suas vantagens ou desvantagens estão sujeitås do interesse que guia quem as 
por objetivo precisar o entendimento sobre o que se chamou conceito científico de processo administrativo. Muitas classificações de processo administrativo existem na doutrina, mas não se vê utilidade aqui em repeti-las. Para o propósito fíxado a exposição de apenas uma classificação faz-se necessária: processos administrativos de defesa e processos administrativos de participação. Essa classificação tem como critério diferenciador a finalidade do processo administrativo.

\subsubsection{Processos administrativos de defesa}

O processo administrativo tem dois escopos básicos: possibilitar o exercício da função administrativa e garantir o direito de participação do administrado. Há no entanto, processos administrativos em que o direito assegurado ato administrado não é somente um direito político de participação. O segundo desígnio anteriormente mencionado, garantia ao direito do cidadão. é acrescido de um plus. Há uma garuntia individual, no sentido técnico da expressão. Segundo José Afonso da Silva garuntia constitucional individual exprimi "os meios, instrumentos, procedimentos e instituições destinados a assegurar o respeito, a efetividade do gozo e a exigibilidade dos direitos individuais, os quais se encontram ligados a estes entre os incisos do art. $5^{\circ}$ (da Constituição)". ${ }^{114}$

Processo administrativo constitui garantia individual nos casos indicados no art. $5^{\circ}$, inciso LV, da Constituição da República. O dispositivo reza que "aos litigantes. em processo judicial e administrativo, e aos acusados em geral são assegurados o contraditório e a ampla defesa, com os meios e recursos a ela inerentes". Litígio hí quando existe lide, ou seja, um conflito qualificado por uma pretensão resistida, em que as partes têm pretensões opostas. Exemplos típicos são os processos disciplinar e de lançamento tributário. No primeiro caso a Administração tem a pretensão de punir o agente e este de não ser punido; no segundo, o Fisco tem a pretensão de lançar o tributo e o contribuinte de que ele não seja lançado. Há partes, no sentido técnico da expressão, pois possuem pretensões antagônicas. Esses são os processos administrativos litigiosos e neles a participação do interessado não é apenas um direito político, mas uma garantia individual.

Todavia, o princípio da máxima efetividade ${ }^{15}$ levou ao entendimento. hoje praticamente pacificado. de que a palavra litígio tem o significado de qualquer controvérsia em torno de um direito (em sentido amplo) do administrado. ${ }^{16}$ Relem-

formula..." Notas sobre derecho y lenguaje. 4. ed. correg. y aum. reimpr. Buenos Aires: AbeledoPerrot, 1994. p. 99.

114 Curso de Direito Constitucional Positivo. 11. ed. rev. Sĩo Paulo: Malheiros. 1996, p. 394-400. 115 J. J. Gomes Canotilho conceitua o princípio da máxima efetividade. também chamado princípio da eficiência ou princípio da interpretação efetiva da seg̣uinte maneira: "a umat noma constitucional deve ser atribuido o sentido gue maior eficácia the dê". Direito Constitucional e Teoria da Constituição. 4. ed. Coimbra: Almedina, 2000. p. 1187.

116 Nesse sentido Lúcia Valle Figueiredo: “quanto à denominação 'litigante em geral'. sempre que 
bram-se os processos de jurisdição voluntária: não há partes, no sentido técnico, pois não há pretensões antagônicas, mas há, eventualmente, controvérsia. O processo de curatela dos interditos (Código de Processo Civil, arts. 1.177 a 1.186) é um bom exemplo: o requerente não tem, simplesmente, a pretensão de interditar o requerido, tanto que age no interesse do interditando e não na defesa de seu próprio interesse, não há interesses contrapostos. Nem por isso deixa de haver controvérsia: o interditando pode impugnar o pedido (art. 1.182 do Código de Processo). Nos casos em que o administrado pretende algo da Administração, contratar com ela, num processo licitatório, obter uma licença, obter uma autorização, etc., não há propriamente um litígio, ${ }^{117}$ pois a Administração não tem a pretensão de negar o pedido do administrado e sim de melhor realizar o interesse público. Mas há sempre uma controvérsia em torno de um direito do administrado: sempre há a possibilidade de a Administra̧̧ão não considerar que o deferimento do pedido vai ao encontro do interesse público. Todos os processo em que há controvérsia em torno de direitos estão compreendidos no termo "litigantes". 118

Resta a expressão "acusados em geral". Por uma interpretação meramente gramatical o adjunto adverbial de lugar "em processo judicial e administrativo" aplicar-se-ia tão-somente aos litigantes. Gramaticalmente, deveria ser colocado após o segundo núcleo do sujeito, "acusados em geral", para se referir também a este: "aos litigantes e aos acusados em geral, em processo judicial e administrativo". Há duas razões que justificam outra interpretação: a primeira é o princípio da máxima efetividade e a segunda é a de que acusados só o são em processos judicial ou administrativo. O Estado não tem outro meio de acusar o cidadão, a não ser num processo. Por força disso, apesar da criticável redação, extrai-se que nos processo administrativos em que haja litigantes e nos processos administrativos em que haja acusados em geral incidem os princípios do contraditório e da ampla defesa.

Presume-se a não existência de palavras inúteis no texto e, por isso, ambos deveriam ser diferenciados. ${ }^{119}$ Não há como negar, no entanto, que a diferenciação

houver controvérsia, conflitos de interesse, haverá aplicabilidade do contraditório e da ampla defesa. nos termos constitucionais". (2003, p. 419).

117 Haverá litígio em sentido técnico sempre que houver mais de um administrado interessado, não entre a Administração e os administrados, mas entre os próprios administrados. É o que ocorre no processo de licitação.

118 Não basta a controvérsia. mas que esta se dê sobre um dircito do administrado. Direito aqui é tomado em sentido amplo: nào abrange apenas os direitos subjetivos. Os administrados tem o direito, seja simples interesse, seja ocalsionalmente protegido, seja imperfeito, de contratar com o poder público, de ser contratado, desde que presentes os requisitos legais. Assim. constatado ser o melhor candidato e a Administração resolver preencher o cargo vago, o administrado tem o direito de ser nomeado. Se apresentar a melhor proposta e a Administração resolver efetuar a compra, tem o direito de vender-lhe seu produto. Sobre os conceitos de interesses simples, ocasionalmente protegidos e imperfeitos vide MANCUSO, Rodolfo de Cimargo. Imteresses Difusos: conceito e legitimação para agir. 5. ed., ver. e atual. São Paulo: Revista dos Tribunais, 2001, p. 17 et seq.

119 Lúcia Valle Figueiredo entende que a expressão "litigante em geral" abrange qualquer controvérsia e "acusados em geral" qualquer imputação de falta ou ilicitude (2003, p. 419). 
entre litígio e acusação soa forçada e artificial. Em última análise onde há uma acusação, há também um litígio. A utilização das expressões pelo constituinte, diante do fracasso de uma rigorosa diferenciação científica, nem por isso deixa de ter uma explicação. A Constituição Brasileira de 1988 é posterior a um longo período ditatorial. Esse fato explica a preocupação do constituinte em enfatizar determinados direitos e garantias. Resplandece que o constituinte exerceu a função enfática de duas maneiras: 1) Pela simples repetição do mesmo termo ${ }^{120}$;2) Pela utilização de dois termos, em que um é abrangido pelo outro. ${ }^{121} \mathrm{Na}$ utilização das expressões "acusados em geral" e "litigantes" parece que, sem desprestigiar outros entendimentos, ocorre o segundo caso mencionado: reiteração da mesma idéia em função enfática pela utilização de dois termos em que um é abrangido pelo outro.

Nos processos administrativos em que há uma controvérsia sobre um direito (em sentido amplo) do administrado, qualquer que seja ela, incidem os princípios do contraditório e da ampla defesa. daí a denominação dada acima: são processos administrativos de defesa. Nesses, o acusado ou litigante tem o direito de participação, de influir na decisão final. Mas. esse direito político é acrescido de um plus: trata-se de uma garantia constitucional individual que dá ao administrado um leque muito maior de situações jurídicas, próprias do princípio do contraditório.

\subsubsection{Processos administrativos de participação}

A Administração, conforme exaustivamente exposto, não pode proferir uma decisão sem a participação do cidadão, sob pena de ilegitimidade. Decisões isoladas, tomadas livremente pelo agente e baseadas somente em sua vontade, são autoritárias, incompatíveis com o Estado Democrático. O exercício da função administrativa implica numa série de decisões e estas, para serem tomadas, exigem, sob pena de ilegitimidade, o processo. ${ }^{122}$ Assim, ainda que não haja nenhuma controvérsia entre Administração e administrado em torno de um direito deste. o processo é necessário para que se permita ao cidadão participar do exercício do poder pela Administração: ${ }^{123}$ daí ser chamado de processo administrativo de participação. Na doutrina

120 Mencionou o princípio da igualdade no preâmbulo; no inciso IV do art. $3^{\prime \prime}$; no caput do ant. $5^{\circ}$, no inciso XXI do art. 37; no inciso II do art. 150, no inciso 1, do art. 206 e no inciso IV. $\$ 3^{\circ}$, do art. 227. A repetição tem tão somente função enfática.

121 Exemplo típico dá-se no inciso LXXI do art $5^{\circ}$. ao afirmar que o mandado de injunção conceder-se-á "sempre que a falta de norma regulamentadora torne inviável o exercício dos direitos e liberdades constitucionais e das prerrogativats inerentes à nacionalidade. à soberania e à cidadania". Evidente que nos direitos constitucionais jă estão incluidas as liberdades e as prerrogativas inerentes à nacionalidade, à soberania e à cidadania. A reiteração, também aí, teve função enfática.

122 Por exemplo: decidir se realiza uma obra, onde realizar essa obra e qual bem desapropriar.

123 Controvérsia em sentido amplo sempre há. Se o administrado. por exemplo, pretende sejam investidos os recursos públicos em determinado setor, sempre haverá a possibilidade de a Administração entender que referido investimento não é a melhor forma de atender ao interesse público. Ao contrário dos processos de defesa, no entanto, a controvérsia nos processos de participação não se dá em torno de um direito do administrado: este tem o direito de participar da decisão adminis- 
brasileira há quem tenha percebido essa nova fase do Direito Administrativo, em que a democracia é valorizada e o processo administrativo é tomado como seu principal meio de concretização. Gustavo Henrique Justino de Oliveira. em primoroso ensaio teceu valiosas observações:

Em face disso, teve início no Brasil a real democratiąçăo. a ser implementada por intermédio da participação popular na Administraçĩo Pública e, principalmente, através da democracia participativa.

Entretanto, forçoso é admitir que processo e participação são institutos indissociáveis: Na feliz colocaçẫo do arg̣entino Roberto Dromi, processo administrativo é o instrumento jurídico que viabiliza o exercício efetivo da participação dos cidadãos; é "a ferramenta jurídica idônea a regular as relações entre governantes e governados". ${ }^{24}$

O processo administrativo é o mais importante meio de democratização administrativa. Pode parecer, numa leitura apressadat, que a instauraçâa do processo dé-se apenas paral atender ao segundo dos dois desideratos fíxados no item 3.7, ou seja, que o processo administrativo vise tão-somente possibilitar a participação dos administrados e não o bom cumprimento da função administrativa. Ocorre que toda participação dos administrados, seja a título de defesa, seja a título de participação estrita, presumidamente sempre aprimora o agir administrativo. Quer diz: presume-se que a decisão tomada com a participação dos interessados seja melhor, enfim. mais consentânea com o interesse público, do que sem ela. Se por um lado. o princípio da eficiência e o princípio democrático estão em constante colisão, por outro, entrelaçam-se em contribuição recíproca. E isso foi notado pela melhor doutrina. Eis as lapidares considerações de Eduardo García de Enterría e Tomás-Ramón Fernandez:

De todo modo há que acrescentar o fato, indiscutivel no contexto sócio-econômico e jurídico-político que nos encontramos, de que sem uma associação efetiva dos cidadãos ao processo de adoção de decisões capaz de despertar sua confiança e de assegurar sua adesão não é possível hoje suprir o déficit de legitimação que resulta da dificuldade de predeterminar normativamente o modo em que a Administração tem de cumprir as tarefas de regulação, configuração e controle social que reclama o conceito mesmo de Estado social de Direito. Não o é tão pouco assegurada a eficácia de nenhuma política, uma vez comprovada a impossibilidade de administrar mandando, especialmente naqueles setores, como os econômicos e sociais, nos quais a

trativa, mas nîo tem o direito, nem em sentido amplo. de que us recursos sejam apliciados conforme slia vontade.

124 As andiencias Publicas e o Processo Administrativo Brasileiro. Revista Trimestral de Direito Público. Sĩo Paulo, n. 21, 1998. p. 163. 
Administração necessita inescusavelmente da colaboração dos administrados para alcançar os objetivos que considera socialmente desejáveis. $O$ procedimento administrativo tende. assim, a converter-se, tanto por razões de legitimidade como por razões de eficácia, em uma instituição central do Direito Público de nossos dias. ${ }^{125}$

O registro desta lição é de vital importância: o direito à participação não é um mal ao exercício da função administrativo e um bem à democracia; é um bem também, às vezes até imprescindível. para o agir administrativo. O administrador na maioria das vezes não tem todas as informações necessárias para o melhor exercício de sua função, ou seja, para a realização máxima do interesse público. Necessita de informações, de elementos que só são obridos através da atuaçăo do cirladĩo. É o chamado papel informativo do processo administrutive. Gustavo Henrique Justino de Oliveira observou, com absoluta razão. que as audiências públicas "habilitam o órgão administrativo 'decididor', tornando-o apto a emitir um provimento mais acertado e mais justo, pois estabelece um maior conhecimento acerca da sujeição subjacente à decisão administrativa". 20

Tanto a Lei Federal brasileira de Processo Administrativo (Lei 9.784/99). quanto a Lei paulista (Lei 10.177/98), em boa hora, positivalam os institutos fundamentais do processo administrativo de participação: a audiência e a consulta públicas. A Lei Federal trata do assunto nos arts. 31, 32, 33 e 34 e a Lei Paulista, em redação idêntica, nos arts. $28,29,30$ e 31 . Os três primeiros merecem integral transcrição:

Quando a matéria do processo envolver assunto de interesse geral, o órgão competente poderá, mediante despacho motivado, abrir periodo de consulta pública para manifestação de terceiros, antes da decisão do pedido, se não houver prejuizo para parte interessada. (grifou-se).

$\$ l^{\circ}$. A abertura da consulta pública será objeto de divulgação pelos meios oficiais, a fim de que pessoas físicas ou jurídicas possam examinar os autos, fixando-se prazo para oferecimento de alegações escritas.

$\$ 2^{\circ}$. O comparecimento à consulta pública não confere, por si, a condição de interessado do processo, mas confere o direito de obter da Administração resposta fundamentada, que poderá ser comum a todas as alegações substancialmente iguais. (grifou-se).

Antes da tomada de decisão, a juízo da autoridade. diante da relevância da questão, poderá ser realizada andiência públic a para debates sobre a matéria do processo. (grifou-se).

125 ENTERRIA; FERNÁNDES. 2002, p. 446-447, tradução nossa 126 OLIVEIRA, 1998, p. 168. 
Os órgãos e entidades administrativas, em matéria relevante, poderão estabelecer outros meios de participação de administrados, diretamente ou por meio de organizações e associações legalmente reconhecidas. (grifou-se).

Os dispositivos, se em parte merecem elogios, não estão livres de inconstitucionalidades. Nem a doutrina brasileira nem o legislador conscientizaram-se de que somente em certas situações, muito peculiares, o direito à participação na tomada de decisões pelos agentes públicos é afastado. O princípio democrático, tomado em abstrato, tem uma forte carga. Por isso, em concreto, exige relevantes e excepcionais razões para ser afastado. A instauração de um processo para toda tomada de decisão, salvo exceções decorrentes da ponderação entre outros princípios envolvidos, é uma imposição constitucional implícita. E processo, espera-se ter demonstrado, não se resume ao procedimento. Não basta uma seqüência de atos, há necessidade de instituir em favor do cidadão situações jurílicas que lhe permitam participar do procedimento, ou seja. há necessidade da relação jurídica processual.

Se para tomada de uma decisão a Administração instaurasse um procedimento interno sem dar oportunidade aos cidadãos de participar, evidente, haveria apenas procedimento, mas não processo. Nos casos em que não há controvérsia em torno de direitos do administrado, os institutos da consulta e audiência públicas são condição indispensável para existência de processo administrativo, pois é através deles que se instaura a situalção jurídica de ônus dos cidadãos interessados e a situação jurídica de dever do Poder Público de ouvir os cidadãos e apreciar os elementos por eles trazidos. Em outras palavras: a relação jurídica processual instaura-se no procedimento através desses institutos. Nesses termos, toda restrição indevida à efetivação das consultas e audiências públicas é inconstitucional.

É óbvio que, diante do caso concreto, cabe a agente público efetuar a ponderação de interesse entre os princípios envolvidos e apurar se o princípio democrático é ou não afastado. Exemplificativamente, num caso urgente, em que a segurança ou a saúde da população fosse atingida se não tomadas providências imediatals, circunstância em que o princípio do interesse público tem maior peso do que o princípio democrático, cabe ao administrador tomar as medidas necessárias sem a abertura do processo administrativo de participação (e, conseqüentemente, sem a realização de consulta e audiência públicas). Essa ponderação pode ser, eventualmente, antecipada pelo legislador na edição de uma regra jurídica, mas sempre deverá ser confirmada no caso concreto pelo administrador. ${ }^{127}$

Percebe-se, assim, que a realização de consultas e audiências públicas não é uma faculdade da Administração. Elas poderão não ser realizadas se, diante do caso concreto, a ponderação entre os princípios envolvidos afastar a incidência do princípio democrático que exige sua realização. Em caso contrário elas se impõem, ainda que cause prejuizo a parte interessada. A ressalva do art. 31, caput, da Lei Federal e do art. 28, caput, da Lei Palulista é, por força disso, inconstitucional.

127 Sobre a colisão de princípios e sua ponderação, reitera-se. é imprescindível a leitura de Alexy (2002). 
Além disso, dependendo do caso concreto, não há nenhum sentido ná realização de audiência pública. Suponhamos que com a consulta pública, os cidadãos interessados, por exemplo, tenham trazido ao processo documentos. Não há o que se esclarecer nem depoimentos a colher. ${ }^{28}$ Nem no processo judicial far-se-ia uma audiência, ${ }^{129}$ por que estaria o administrador, ressalvadas situações peculiares, obrigado a fazê-la? É evidente que cabe ao próprio administrador decidir, diante do caso concreto, salvo nos casos em que a lei expressamente exija sejam realizadas (ressalva constante de ambas as leis: art. 69 da Lei Federal e $1^{\circ}$ da Lei Paulista), se basta a realização de consulta pública ou é necessária também a realização de audiência pública e/ou de outras formas de participação da população. Percebe-se que a consulta pública é o mínimo, é a situação jurídica de ônus necessária para fazer do procedimento de decisão um processo. Assim, a consulta pública é um dever do Administrador e não uma faculdade, só afastado se. diante de uma ponderação entre os interesses envolvidos, outros princípios tenham maior peso que o princípio democrático que exige sua realização. A audiência pública e outras formas de participação serão realizadas ou não, dependendo do calso. Mas também não se trata de faculdade. Diante das circunstâncias, necessidade da collheita de testemunhos, por exemplo, o administrador tem o dever de realizá-las e, na ausência dessas circunstâncias, tem o dever de não realizá-las. ${ }^{130}$

A dicção do $\$ 2^{\circ}$ transcrito demanda algumas observações. O comparecimento do cidadão não o faz interessado no sentido de parte. Trata-se de processo administrativo de participação e não de defesa. O cidadão é interessado na decisão e por isso tem o ônus de participar da consulta, mas não é parte do processo. não tem o direito de se defender. Essa é a exegese do dispositivo. Os dispositivos legais indicam a possibilidade de, em certos processos de defesa, realizarem-se consultas e audiências públicas e isso merece elogios. Haveria, nesse caso. um processo misto, de defesa e de participação, em que, no mesmo processo assegure-se ao acusado ou litigante a defesa e aos cidadãos, a participaçũo política. Evidente, no entanto. que isso só deve ocorrer excepcionalmente, quando o processo de defesa seja de interesse da população em geral. Não é o que ocorre no mais das vezes: na maioria dos processos de defesa é ilegítima a participação dos cidadãos, só indiretamente interessados na decisão. ${ }^{131}$

128 Observa-se não se tratar, en rigor científico. de provals, posto que nāo há litígio. Há casos em que os interessados necessitam trazer aus autos depoimentos, não a título de prova, mas a título de participação política. Por exemplo: para demonstrar que uma obra deve ser construída, o administrado traz à administração o testemunho de várias pessoals sobre sua imprescindibilidade.

129 Nesse sentido dispõe o artigo 330 do Código de Processo Civil.

130 A realização de audiências públicas inúteis representa desperdício do erário não autorizado, por óbvio, ao administrador. Assim, nos casos em que al audiêncials não são necessárials para a participação dos cidadãos, há um dever jurídico de não realizá-las.

131 Não se exclui, no entanto, o interesse desses cidadãos em controlar a legalidade desses processos. podendo fazê-lo administrativamente, através do direito de petiçūo. e judicialmente, através da ação popular. 
Essas considerações, necessário dizer. são. por enquanto, isoladas na doutrina. Oxalá nossos administrativistas atentem para o real sentido do princípio democrático em nosso ordenamento e reconheçam as consequiencias que dele decorrem. Em brilhante parecer Marcos Augusto Perez entendeu que a participação popular no processo administrativo só é vinculante para a Administração se houver expressa disposição legal. A Administração, no entanto, poderia se valer das audiência e consulta públicas ou outras formas de participação popular, mesmo sem previsão legal, se estas não forem vinculativas. São suas palavras:

Cremos que, havendo vinculação haverá necessariamente uma quebra da estrutura tradicional de formação da vontade do administrador. quebra do sistema tradicional de construção do ato administrativo. e. portanto. alteração da organização administrativa, dentro de nosso quadro normativo. [...] Desse modo, para que haja alteração organi $a$ ativa, na esteira do texto constitucional. da Administração Pública é necessário que esta se dê através de lei, pois a matérial é de competência do Poder Legislativo.

[...]

Seguindo o mesmo raciocínio, mutatis mutandis, não há necessidade de lei regulamentadora da participação nos casos em que está não assuma o caráter vinculativo da decisão administrativa. ${ }^{132}$

Sem desprestigiar o nobre jurista, não são corretas suas afirmaçōes. A " estrutura tradicional da formação de vontade do administrador" mencionada pelo autor é totalitária e incompatível com o Estado Democrático. De fato. o Brasil viveu a maior parte de sua história em regime ditatorial, por isso sua tradição nada tem de democrática. Diante de uma história de abusos, menos de vinte anos de vigência de uma Constituição-cidadã não são suficientes para consolidar tradição. Nem por isso, todavia, é possível afirmar a admissibilidade de decisões isoladas e livres do administrador como regra. Hoje ao menos, deve-se afirmar exatamente o contrário: consistem em exceção. Além disso não é possível afirmal que o resultado da participação democrática seja não-vinculativo. De fato, trazidos documentos ao processo pelo cidadão numa consulta pública: colhidos depoimentos numa audiência pública. o administrador, ao decidir, pode ignorar esses documentos e depoimentos alegando que são meramente indicativos, mas não vinculantes? Evidente que não, ao menos no sentido aparentemente pretendido pelo autor. Deverá, necessariamente, apreciar todos os documentos, todos os depoimentos, enfim. tudo que foi dito pelos participantes, e fundamentar o afastamento de cada elemento desconsiderado na tomada da decisão. Mutatis mutandis, é o que o que ocorre no processo judicial. O juiz não está vinculado a nenhuma prova, nem à pericial, mas também não pode simplesmente afastar a prova por sua livre e espontânea vontade. Deve examinar cada prova e fundamentadamente afastá-la. Cada elemento trazido pelo cidadão ao processo ad-

132 Participaçâo popular na Administração Páblica. Revista Trimestral de Direito Público. São Paulo. n. 31. 2000. p. 133-134. 
ministrativo, da mesma forma, deve. necessária e imperativamente, ser analisado pelo administrador quando do proferimento da decisíto tínal.

Audiência pública, registra-se, não se confunde com pública audiência ou sessão pública, não observação sagaz de Gordillo, pois não basta a alssistência passiva e muda do público, "[...] senão de realizar uma audiência na qual o público é parte interessada e ativa, $[\ldots]$ com direito de oferecer, produzir prova e controlar o que se produz, alega etc." 133 Deve-se enfatizar que o processo de participação só é um processo porque há uma relação jurídica complexa entre os interessados e a Administraçâo, ou seja, há um conjunto de situições jurílicas sucessivas, ao longo do procedimento, formadoras da relação jurídica processual. Esta se caracteriza primordialmente pelo fato de os administrados terem o ônus de trazer elementos ao processo e a Administração o dever de examiní-los. Por isso que a denominada pública audiência, também chamada sessão pública, em que a Administração simplesmente torna públicos os atos internos que pratica. não é elemento essencial do processo administrativo.

Em síntese, nos casos em que não há controvérsia sobre um direito (em sentido amplo) do administrado, a Administração não tem que instaurar um processo administrativo de defesa e observar o princípio do contraditório. Mas para tomar uma decisão, nesses casos, em regra, tem que instaurar um processo administrativo de participação, pelo qual uma série de situações jurídicas seja instituída em favor dos cidadãos, permitindo-lhes influenciar na decisão a ser tomada.

\subsection{Procedimentos administrativos autônomos}

Se um ato final, para ser proferido, necessita da prática de outros atos, em que cada um é consequiência do anterior e condição necessária do posterior, todos ligados pelo mesmo fỉm, ou seja, à prática do ato conclusivo, tem-se um procedimento. Processo é a ligação indissociável entre o procedimento e uma relação jurídica complexa, nele vigorante. No exercício da função jurisdicional não existem procedimentos autônomos: em todos os procedimentos há essa relação jurídica processual. $\mathrm{Na}$ função administrativa, no entanto, procedimentos administrativos autônomos são comuns.

Suponha-se que num processo judicial tenha-se determinado à administração o depósito dos honorários periciais. A efetivação do depósito não é uma decisão, mas o cumprimento de uma decisão. É, na verdade, a prática de um ato material, ou seja, de um ato não-declarativo, de um comportamento praticado espontaneamente pela Administração em que ela exerce sua vontade, mas não manifesta uma declaração lingüística de vontade. Para efetivar esse depósito. a Administraçióo tem que praticar uma série de atos administrativos, há um procedimento, em que só ela, Administração, participa. Não há necessidade, pois não está tomando uma decisão. da instauração de um processo. O procurador atuante no processo judicial requisita a instau-

133 GORDILLO, 1998, p. X-11, tradução nossa. 
ração de um expediente e apresenta documentos comprobatórios do requerimento judicial de depósito. Esse expediente é encaminhado ao departamento contábil que processa a solicitação. Após. é enviado ao Departamento do Tesouro que empreende a liberação da verba requerida. Muitos atos administrativos são praticados, numa série ordenada, todos ligados ao objetivo final, ou seja. ao ato material de depósito. Apesar de existir procedimento em sentido técnico, não há que se falar em relação jurídica processual, pois só ågentes da própria Administração atuam no expediente. A relação entre os agentes e a Administração é uma relação de direito material decorrente do vínculo estatutário que nada tem a ver com o expediente em si, não sendo, por isso, processual. Conclui-se: trata-se de um procedimento administrativo autônomo.

Os procedimentos administrativos autônomos surgem sempre que a Administração precisa praticar um ato material e para tanto é necessária a prática de mais de um ato administrativo. Surge também nos raros casos em que a Administração precisa tomar uma decisão, mas, por força de circunstâncias peculiares do caso concreto, o princípio democrático que exige a realizaçĩo do processo de participação é afastado pelo princípio do interesse público (defésa da salúde ou segurança da população, por exemplo).

No quotidiano da Administração, os agentes públicos em geral, por praxe, denominam os procedimentos administrativos autônomos de processos administrativos. Seja processo seja mero procedimento tudo é denominado de processo. Corrente é a abreviação - P.A. Cientificamente, no entanto, só quando ao particular são conferidas situações jurídicas que the permitam influenciar na prolação do ato conclusivo haverá relação jurídica processual e, por essà razão, processo. Nos demais casos, em que só atuam agentes da própria administração. há, tão-somente, procedimento.

\subsection{A competência legislativa}

Afirmou-se que todas as conclusões do capítulo anterior, obtidas a partir da doutrina formulada na seara do Direito Processual Civil. são aplicáveis integralmente ao Direito Administrativo. Afirmou-se que o conceito de processo era necessariamente diferente do conceito de procedimento, alo menos no Brasil, por imposição dogmática: o art. 24, XI da Constituição da República. Essa tese exigiu, ainda que superficialmente, um exame das competências legislativas para legislar sobre processo e procedimento.

Por força disso, visando evitar possível confusão, faz-se necessário afirmar desde logo: os arts. 22, I e 24, XI não tratam da competência para legislar sobre processo administrativo. A Constituição de 1988 disciplinou a competência para legislar das entidades federativas, principalmente. em quatro dispositivos: nos arts. 22, 24, 25 e 30. Previu-se até o direito espacial, mas em nenhum deles, o Direito Administrativo. Não foi esquecimento do constituinte: legislar sobre direito administrativo é decorrência lógica da autonomia política do ente federativo, expressamente prevista no art. 18. Sempre que o constituinte quis excepcionar essa regra o 
fez expressamente, como, por exemplo, no inciso XXVII do art. 22. Não havendo referência expressa nos incisos I do art. 22 e XI do art. 24 ao Direito Administrativo a regra geral permanece incólume: esses dispositivos só se aplicam à função jurisdicional. Legislar sobre o processo e procedimento administrativos de cada entidade federativa compete à respectiva entidade.

Essa conclusão em nada modifica todas as conclusões anteriores. Se para a função jurisdicional processo e procedimento são institutos diferentes por imposição dogmática, igualmente também o são para a função administrativa. A redação do referido art. 24 , inciso XI, ao disciplinar o exercício da função jurisdicional, fez menção a dois institutos da Teoria Geral do Direito, tomando-os como diferentes. Além disso, como já afirmado, ${ }^{1.34}$ o constituinte utilizou a expressão processo administrativo em vários dispositivos e nada indica tenha tomado a palavra processo aí em sentido diferente da que tomou quando se referiu ao processo jurisdicional.

Em síntese, esclarecida a possível confusĩo, a competência para legislar sobre processo e procedimento administrativos é da respectiva entidade federativa que os exerce. Dito isso, enunciados os conceitos de processo e procedimento administrativo, discorrido sobre os escopos do processo administrativo. sobre suas espécies e sobre o procedimento administrativo autônomo, resta, para concluir o objetivo proposto, o exame dos princípios que regem o processo administrativo. A análise dos princípios regentes é fundamental para a exata compreensão de seu conceito científico.

\section{Princípios Regentes Do Processo Administrativo}

\subsection{Breve introdução}

O conceito científico de processo proposto nesta modesta análise só será devidamente compreendido se examinados seus princípios regentes. Uma conclusão óbvia pode, desde já, ser fixada. Se por um lado o processo administrativo é um meio de exercício da função administrativa, por outro, ele próprio consiste nesse exercício. Ao instaurar um processo administrativo e ao presidi-lo, a Administração está exercendo função administrativa. Por força disso, regem o processo administrativo todos os princípios que regem a função administrativa. ${ }^{1.35}$

Sendo o processo administrativo exercício da função administrativa, os princípios estruturantes do Direito Administrativo, da supremacia do interesse público

\section{Supra, 3.5.}

135 Princípios são mandados de optimização realizáveis de acordo conn as circunstâncias fáticas e jurídicas. É o conceito de Robert Alexy. Sistema Jurídico, Princípios Jurídicos y Razón Práctica. In Derecho y Razón Práctica. 2. reimpr. corrig. México: Fontamara, 2002, p.7-24. A teoria é exposta com mais detalhes em Teoria de los Derechos Fundamentales. Tradução de Ernesto Garzón Valdés. 1. ed., 2. reimpr. Madri: Centro de Estudios Políticos Y Constitucionales, 2002. Sobre uma crítica à teoria de Alexy vide ÁVILA (2003). 
sobre o privado e da indisponibilidade do interesse público. ${ }^{130}$ são também suas vigas mestras. Todos os princípios deles decorrentes, sejam os expressamente previstos na Constituição, sejam os implicitamente dela extraílos, são também at ele aplicáveis. ${ }^{137}$ Não por serem regentes do processo administrativo em si, mas por serem regentes da função administrativa.

O problema maior a ser enfrentado. que exige detida analise, é apuar quais os princípios peculiares ao processo administrativo. Os princípios inerentes à função administrativa são obviamente aplicáveis ao processo, resta examinar quais princípios incidem, não em decorrência do exercício da função administrativa, mas em virtude do processo em si mesmo considerado. Esse é objetivo deste capítulo.

\subsection{Os sistemas administrativos}

Sistema administrativo ou sistema de controle jurisdicional da Administração é o regime adotado pelo ordenamento jurídico para correção dos atos administrativos ilegais. ${ }^{138}$ Existem dois: o chamado contencioso administrativo ou francếs e o judiciário, de jurisdiçáo linica ou inglés. O primeiro foi adotado originariamente na França, em radical concretização ao princípio da separação dos poderes. É tundamentado no seguinte raciocínio: se fosse dado ato Judiciário o poder de se manifestar sobre a atividade administrativa do Executivo estaria abalada a separação entre este poder, Executivo, e àquele, Judiciário. Daí ser vedado à Justiça comum, como regra geral, conhecer dos atos administrativos praticados pelo Executivo. Esses são conhecidos por uma jurisdição especial, chamada jurisdição administrativa, ${ }^{13 y}$ pertencente à organização do próprio Executivo.

136 Adota-se aqqui a concepçäo de Celso Antonio Bandeira de Mello sobre o regime juridico-administrativo (2001, p. 25 et seq.).

137 Assim. não há dúvida de que os cinco princípios arrolados no caput do art. 37 da Constituição de 1988 aplicam-se alo processo administrativo: legalidade, impessoalidade, moralidade, publicidade e eficiência. Todos os demais princípios não expressamente previstos. mas extraídos pela doutrina da análise dos dispositivos do texto constitucional, aplicávicis a função administratival também se aplicam ao processo administrativo. São exemplos: os princípios da motivação. da finalidade. do controle judicial dos attos administrativos, da responsabilidade do Estado por atos administrativos e da segurança jurídica.

$138 \mathrm{O}$ conceito é de Hely Lopes Meirelles (1981. p. 28).

134 Hely Lopes diferencia o contencioso administrativo da jurisdição administrativa. Açuele se refere ao conjunto de litígios resultantes da atividade administrativa. Jurisdição administrativa, por sua vez, consiste no conjunto de tribunais agrupados sob a autoridade do Conselho de Estado, órgão de cúpula dessa jurisdição especial pertencente ao Poder Executivo. Jurisdição administrativa diferencia-se da jurisdição judiciária, ou seja, dos tribunais agrupados sob a autoridade da Corte de Cassação, órgão de cúpula do Poder Judiciário. (1981, p. 28-29). A jurisdição administrativa sempre foi menos ampla que o contencioso administrativo, pois alguns litígios referentes à Admi. nistração sempre couberam à justiça conum, como. por exemplo. os litigios decorrentes das atividades públicas de caráter privado (no Brasil denominadas de exploração de atividade econômica: art. 173. captut da CF/88). 
No contencioso administrativo, os conflitos em çue a Administração pública esteja envolvida são resolvidos por ela própria, ressalvadas algumas exceções. Para solução desses conflitos a administração vale-se, evidentemente. de um processo administrativo. Ocorre que esses processos, que levam à coisa julgalda, existentes no sistema francês, nada têm a ver com os processos administrativos aqui examinados, que não levam à coisa julgada. ${ }^{140}$ Aqueles são jurisdicionais, pois a Administração dita definitivamente o direito no caso concreto; estes são não-jurisdicionais, pois sempre são passíveis de revisão. A afirmação de que processo administrativo em si mesmo consiste no exercício da função administrativa aplica-se tão-somente aos processos não-jurisdicionais. Os jurisdicionais, próprios do contencioso administrativo ou sistema francês, consistem em exercício da função jurisdicional. As conseqüências disso são importantes: aos processos administrativos jurisdicionais do contencioso administrativo, por se tratarem de exercício da função jurisdicional, aplicam-se todos os princípios do processo civil ou penal e não da atividade administrativa.

No sistema judiciário, ou de jurisdição única, ou inglês não há essa divisão: todos os atos administrativos, sem exceção, são passíveis de exame pelo Poder Judiciário. Vigora com toda força, sem admitir exceções, o princípio do não afastamento do controle judiciário oul. em outras palavras. o direito fundamental à ação jurisdicional (art. $5^{\circ}, X X V$, da Constituição). Nesse sistema a regra é que a função jurisdicional é privativa do Poder Judiciário, só a ele cabe decidir definitivamente sobre um conflito de interesses, dizendo o direito no caso concreto e produzindo coisa julgada. ${ }^{141}$ Nesse sistema só existem processos administrativos não-jurisdicionais, consistentes no exercício da função administrativa.

O Brasil adota o sistema inglês: não admite processos administrativos jurisdicionais. Nos processos administrativos graciosos ou não-jurisdicionais, únicos existentes, é incontroversa a incidência dos princípios regentes da função administrativa. Discute-se, no entanto, quais os princípios, próprios do processo jurisdicional, incidem no processo administrativo não-jurisdicional. Um dos motivos para a adoção do termo "processo administrativo" preconizado por Adilson Abreu Dallari e Sérgio Ferraz é justamente a aplicação ao processo administrativo dos princípios do processo jurisdicional. ${ }^{142}$ Quase toda doutrina nacional acompanha esse pensamento. ${ }^{143} \mathrm{Lu}-$

140 Relembra-se a útil terminologia adotada por Marcelo Caetano: os jurisdicionais são chamados de processo administrativos contenciosos: os não-jurisdicionais de graciosos. No sistema francês existem tanto processos administrativos contenciosos quanto graciosos. No sistema inglês existem, tão-somente, os graciosos.

141 Exceções, quando existem, são raras. No Brasil, por exemplo, cabe ao Senudo Federal julgar definitivamente os crimes de responsabilidade praticados pelos Ministros do Supremo Tribunal Federal, pelo Procurador Geral da República. pelo Advogado-Geral da União, pelo Presidente e Vice-Presidente da República e, nos crimes conexos com os destes, os Ministros e Comandantes da Marinha, do Exército e da Aeronáutica (Constituiçĩo Federal, art. 52. incisos I e II). Trata-se de função jurisdicional exercida atipicamente pelo Legislativo.

142 FERRAZ: DALLARI. 2001 , p. 35.

143 Carlos Ari Sundfeld afirma: "Importantes doutrinadores sustentam ser fundamental falar em 
cidamente, Garcia de Enterría e Tomás-Ramón Fernández desaconselham o uso da expressão "processo administrativo" por razões opostas, para que não se cometa o disparate pretendido pela doutrina brasileira de se aproximar indevidamente o processo administrativo do processo jurisdicional. A lição. pela sua importância, merece ser transcrita:

[a contribuição de Merkel] ...ao enfraquecer o monopólio judicial do procedimento, subtraindo a inexistência de interdependência estrutural ou interna entre as distintas classes de procedimentos, tem podido advertir os riscos inerentes aos intentos de assimilação até às últimas consequiências do processo judicial e o procedimento administrativo que, impulsionados pelo legítimo afã de reforçar ao máximo as garantias dos administrados, tendendo a "jurisdicionalizar" em excesso o procedimento administrativo em oposto ao que postulam as concretas necessidades às quais dito procedimento serve. ${ }^{14 t}$

A advertência dos excelsos autores exige séria reflexão. Seria precipitado e um tanto quanto incoerente afirmar, sem a análise suficiente, que ao processo administrativo não jurisdicional aplicam-se todos os princípios do processo jurisdicional. O passo seguinte é, assim. empreender análise comparativa entre o processo jurisdicional (privativo no Brasil, com raras exceções, ao Judiciário ${ }^{15}$ ) e 0 administrativo.

\subsection{Os institutos fundamentais do Direito Processual (jurisdicional) e seus correspondentes no Direito Processual Administrativo}

Muitas semelhanças existem entre o processo judicial e o administrativo já que, cientificamente, o conceito de processo não difere: processo, seja jurisdicional ou administrativo, é o conjunto indissociável de procedimento e relação jurídica processual. A doutrina refere-se a quatro institutos fundamentais do Direito Processual (jurisdicional): jurisdição, ação, defesa e processo. ${ }^{1+6}$ Nem todos esses institutos,

'processo' administrativo justamente para afirmar com ênfase a incidência, nat esfera administrativa, dos grandes princípios processuais (devido processo, ampla defesa, direito ao contraditório e ao recurso, etc.)". (Processo e Procedimento Administrativo no Brasil. p. 19). E acrescenta concordar com a preocupação.

144 ENTERRIA: FERNÁNDEZ, 2002, p. 443, esclarecimento e traduçĩo nossa.

145 Não se confunde processo judicial com processo jurisdicional. Processo judicial engloba os processos de jurisdição contenciosa e os processos de jurisdição voluntária. Estes não são jurisdicionais, posto que não resolvem definitivamente o conflito (nesse sentido. art. 1.111 do Código de Processo Civil), mas não são administrativos, pois são presididos por juiz imparcial dotado dos predicativos da magistratura. Não há, de fato, como comparar um processo administrativo disciplinar instaurado no âmbito do Poder Judiciário pelo juiz-corregedor com um processo de separação consensual. Sobre a jurisdição voluntária vide Cintra: Grinover; Dinamarco, 1998, p. 149-152. Vide também, supra 2.4 .

146 Essa estrutura foi adotada na obra clássica de Eduardo Couture (2002) e seguida por Araújo Cintra, Pellegrini Grinover e Cândido Dinamaırco (1998). 
apesar da identidade conceitual, têm correspondência no Direito Processual Administrativo. Já analisado o instituto do processo, cabíveis algumas considerações sobre os demais.

Jurisdição é a função estatal exercida em substituição às partes envolvidas no conflito, de pacificação deste mediante atuação da vontade do direito objetivo no caso concreto. ${ }^{147}$ É, nesses termos, o exercício do poder estatal. Sempre que o Estado precisa decidir, seja para solução definitiva de um conflito de interesses. substituindo as partes envolvias, seja pela execução de uma política pública, vale-se do processo. Perceba-se, portanto, que, em termos gerais, o processo é necessário para o exercício do poder, sendo a jurisdição e a administração formas de exercício do poder. Jurisdição é o exercício do poder específico do processo jurisdicional. Administração é o exercício do poder específico do processo administrativo. Conclui-se, dessa forma, que o instituto fundamental da jurisdição encontra, sim, correspondência no âmbito administrativo.

A ação, em síntese, é o poder do indivíduo de exigir a prestação jurisdicional. ${ }^{148}$ Aqueles que concebem o processo como meio de tutela a direitos colocam a ação no centro do sistema processual, passando o processo jurisdicional a ser concebido como um instrumento do autor. Essa visão, todavia, está superada: processo jurisdicional não existe para promover o direito do demandante, mas para solucionar definitivamente o conflito. ${ }^{149}$ A antiga concepção era favorecida no processo jurisdicional pelos principios da inércia da jurisdição e da demanda: só há atuação da jurisdição se houver ação. Cândido Dinamarco defende que o instituto da ação não encontra correspondente no processo administrativo, posto que a Administração sempre pode atuar de ofício e iniciar o processo independentemente de qualquer pedido. ${ }^{150}$ Couture, no entanto, considera o direito de ação forma típica do direito de petição ${ }^{151}$ e, apesar da veemente repulsa de Dinamarco, está com a razão. ${ }^{152} \mathrm{O}$ direito de petição, genericamente, refere-se ao poder do indivíduo de exigir do Estado que se manifeste sobre sua pretensão: no processo jurisdicional, dá-se através da ação; no processo administrativo, através de vários instrumentos, tais como o pedido de reconsideração, a representação, a denúncia, a reclamação. ${ }^{153} \mathrm{O}$ instituto da ação,

147 Sobre o conceito vide Cintra, Grinover e Dinamarco, 1998, p. 125 et sec. 148 Sobre o conceito de ação e as várias teorias existentes, vide Cintra, Grinover E Dinamarco (1998, p. 247 et seq.).

149 Nesse sentido DINAMARCO. Os institutos findamentais do Direiro Processual, p. 99-101. 150 DINAMARCO, loc. cit. Fica afastada desde já a incidência dos princípios da inércia da jurisdição e da demanda no processo administrativo: a Administração sempre pode atuar de ofício.

151 COUTURE, 2002, p. 61-65. O direito de petição está previsto no art. $5^{\circ}$, inciso XXXIV, "a", da Constituição brasileira; o direito de ação, no art. $5^{\circ}, \mathrm{XXXV}$.

152 DINAMARCO, op. cit., p. 117.

153 Em sentido contrário, Celso Antonio Bandcira de Mello restringe o direito de petição, gênero abrangente da representação, da denúncia e da reclamação administrativa, a quem não seja parte da relação jurídica em cujo bojo foi tomada a decisão, ou não seja diretamente afetado pela medida ou, em qualquer caso, se a lei não previu recurso para a hipótese especifica. Se o requerente é parte 
apesar de encontrar correspondente no âmbito administrativo, não está, ao contrário do que ocorre no processo jurisdicional, sempre presente. Se o processo jurisdicional é sempre iniciado pela manifestação do direito de ação, o processo administrativo pode ser iniciado de ofício pela Administração.

Defesa consiste na faculdade de resistir à pretensão formulada em juízo. Foi valorizado com a superação da teoria do processo como instrumento do autor. Não se concebem processos jurisdicionais sem que hajat conflito de interesses e, portanto, duas partes: a que veicula a pretensão e a que resiste. ${ }^{154}$ No âmbito administrativo o instituto encontra correspondência, mas nem sempre está presente: defesa só existe nos chamados processos de defesa, não nos de participação. Possui, nesses termos. correspondência, mas não a título fundamental: não se trata de instituto fundamental do processo administrativo.

Em síntese, todos os institutos fundamentais do Direito Processual (jurisdicional) encontram correspondência no Direito Processual Administrativo, não. porém, a título fundamental. O direito de petição, correspondente ao direito de ação, não é categoria indispensável para instauração do processo em face da não aplicação dos princípios da inércia da jurisdição e da demanda e, assim, não é instituto fundamental. $O$ direito de defesa só surge em certos tipos de processos administrativos, não se configurando nos processos de participação. A análise dos institutos fundamentais do Direito Processual jurisdicional revela, pois, acentuadas diferenças entre as duas formas de exercício do poder estatal.

\subsection{Processo jurisdicional e administrativo: diferenças fundamentais}

Feito o exame dos institutos fundamentais do Direito Processual jurisdicional e de seus correspondentes no âmbito administrativo, necessário enunciar as diferenças fundamentais entre ambos os processos. Duas delas extraem-se da análise anterior: 1) no processo administrativo não vigoram os princípios da demanda e da inércia da jurisdição, pois a Administração sempre pode agir de ofício, descaracterizando-se o direito de petição (em sentido amplo) como instituto fundamental; 2) o direito de defesa também se descaracteriza como instituto fundamental, tendo em vista que nem sempre está presente: só surge nos chamados processos administrativos de defesa. Outras diferenças existem, além dessas, de tão ou mais graves conseqüências.

No processo jurisdicional o juiz não é parte do conflito de interesses, da relação jurídica de direito material que envolve as partes, não tem, por força disso, nenhum interesse no conflito em causa. Essa imparcialidade é de extraordinária importância

diretamente interessada deve valer-se do pedido de reconsideração e do recurso hierárquico. (2001. p. 112-115). Com todo respeito pelo jurista de escol, essa diferenciação não é aqui adotada. Direito de petição é o equivalente genérico do direito de ação e abrange todos os instrumentos utilizados para exigir a manifestaçĩo estatal, seja jurisdicional, scja administrativa.

154 São comuns processos judiciais em que o instituto não está presente. Trata-se dos processos de jurisdição voluntária, tais como a arrecadação de coisals vagas, a organização de fundações. Esses, no entanto, não são jurisdicionais (supra, nota 142). 
no processo jurisdicional na medida em que é uma das maiores garantias de uma decisão justa. No processo administrativo, a Administração, encarregada de proferir a decisão final, é parte no conflito de interesses ou na relação jurídica de direito material. Tem o dever de impessoalidade, que não se confunde com imparcialidade. Impessoalidade é agir tendo em vista, não o interesse próprio (pessoal), mas o interesse público. Não exige isenção, não exige, portanto, imparcialidade.

O produto final do processo jurisdicional, ao menos o produto pretendido, é dotado da característica de definidade, efeito da coisa julgada: a decisão proferida não pode ser modificada. Pelo princípio do não afastamento do controle judiciário, vigorante no sistema de jurisdição única, o processo administrativo nunca faz coisa julgada. A decisão proferida em sede administrativa sempre é passível de reexame pelo Judiciário, em sede jurisdicional.

Por fim, ao processo jurisdicional aplica-se o princípio do devido processo legal, princípio geral, concretizado por uma série de princípios processuais: contraditório, ampla defesa, juiz natural, imparcialidade, dentre outros. A doutrina, praticamente pacífica, defende a incidência do princípio do devido processo legal no processo administrativo. O exame científico não se contenta com o argumento de autoridade e, por isso, para evitar equívocos decorrentes de generalizações indevidas. muitas vezes ideologicamente plantadas, faz-se necessária percuciente análise para saber se e em que medida esse princípio é de fato aplicável. É o que se fará a seguir.

\subsection{O Devido Processo Legal: conceito}

O princípio tem sua origem remota na Magna Carta inglesa, de 1215 , fruto de um acordo entre o rei João Sem Terra e os barões ingleses. Constava do art. 39 da Magna Carta ${ }^{155}$ o law of the land, ou lei da terra. Em 1354. durante o reinado de Eduardo III, a expressão é substituída em uma lei do parlamento por due process of law. Posteriormente, em 1628, Carlos I decretou um empréstimo compulsório ilegal e levou cinco nobres à prisão porque se recusavam a pagá-lo. Por força disso, sob inspiração de Edward Coke, foi elaborado pelo Parlamento Inglês a Petition of Rights, consignando entre as garantias constantes de seu art. 39 a de que ninguém poderia ser preso sem justa causa - whithout any showed. A cláusula, posteriormente, foi inserida na declaração de direitos de muitas das colônias americanas, sendo um exemplo o artigo VIII da Declaração de Direitos do Bom Povo da Virgínia de 1776 que trazia expresso o law of the land. A Constituição Americana, inicialmente, não apresentou um rol de direitos fundamentais. Estes foram inseridos através de Emen-

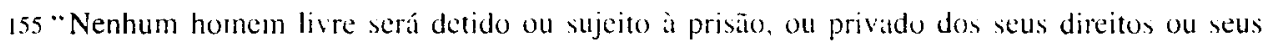
bens, ou declarado fora da lei, ou exilado. ou reduzido em seu status de qualquer outra forma, nem procederemos nem mandaremos proceder contra ele senão mediante um julgamento legal pelos seus pares ou pelo costume da terra." Tradução retirada de MOURA. Elizabeth Maria de. O Devido Processo Legal na Constituiçāo Brasileira de 1988 e o Estado Democrático de Direito. São Paulo: Celso Bastos Editor, 2000, p.41, grifo nosso. 
das, cujas dez primeiras foram redigidas por Madison e aprovadas em 1791. O princípio do due process of law consta da Emenda V, ${ }^{156}$ aplicável, segundo se entendeu, ao Estados. Com o fim da Guerra da Secessão e a imperiosa necessidade de estender o princípio da igualdade aos Estados-membros, editou-se a Emenda XIV em $1865,{ }^{157}$ em que também consta expressamente o due process. Consagrada estava para o resto da história da humanidade a cláusual due process of law, traduzida para o português como "devido processo legal". ${ }^{158}$

Há uma divergência, hoje, sobre o significado dessa expressão, existindo duas concepçôes a respeito. 1) Pela primeira, a cláusula consagra um processo consentâneo com determinadas regras pré-estabelecidas. Esse o sentido, segundo Sampaio Dória, do princípio da lei da terra. Daí, poder-se-ia argumentar, a existência de dois dispositivos distintos na Carta Magna: arts. 39 e $40 .^{159}$ De acordo com essa interpretação, afirmou Melville Bigelow, citado por Dória: " a expressão per legem terrae exigia simplesmente um processo judicial". tanto que as ordálias (juízos de Deus) não contrariavam à law of the land. Sampaio Dória permaneceu fiel a essa concepção, valendo-se da expressão adequado processo legal. ${ }^{100}$ 2) Segundo o Ministro Cezar Peluso devido é aquilo que deve ou precisa ser feito. Uma coisa pode ser devida a título de lei, nesse sentido um ato devido é um ato que o sujeito precisa praticar porque a lei lhe impõe: é devido porque imposto por uma norma jurídica. O processo legal é o processo devido a título de lei. Então. conclui, o devido da expressão "devido processo legal" não pode ter o mesmo significado que legal. O processo, além de estar de acordo com a lei (processo legal), tem que ser devido a título de justiça, tem que ser justo (processo justo). A melhor tradução da expressão seria "justo processo da lei". ${ }^{161}$ Essa é a posição de Charles D. Cole, para quem "o

156 A Emenda V da Constituição americana tem a seguinte redação: " nenhuma pessoa será detida para responder por crime capital ou hediondo, a menos que apresentada ou indiciada por um grande Júri, exceto em casos levantados perante as forças terrestres ou navais, ou milícia, quando em efetivo serviço em tempo de guerra ou perigo público; nem será pessoa alguma sujeita por duas vezes à mesma ofensa, colocando em risco sua vida ou parte do corpo; nem ser compelida em qualquer caso criminal a ser testemunha conta si mesma, nem ser privada da vida. liberdade ou propriedade, sem o devido processo legal; nem a propriedade privada ser tomada para uso público sem justa compensaçīo". Tradução retirada de MOURA (2000, p. 43. grifo nosso).

157 A Emenda XIV tem a seguinte redação: "Todas as pessoas nascidas ou naturalizadas nos Estados Unidos, e sujeitas à sua jurisdição, são cidadãos dos Estados Unidos e do Estado em que residam. Nenhum Estado fará ou executará qualquer lei que restrinja os privilégios ou imunidades dos cidadãos dos Estados Unidos; nenhum Estado privará qualquer pessoa da vida. liberdade ou propriedade sem o devido processo legal: nem negará a qualquer pessoa dentro de sua jurisdição a igual proteção das leis". Tradução retirada de MOURA (2000, p. 44, grifo nosso).

158 Sobre a história da cláusula vide DÓRIA. Antonio Roberto Sampaio. Direito Constitucional Tributário e Due Process of Law. Rio de Janeiro: Forense, 1964. p. 09 et. seq.

$159 \mathrm{O}$ art. 40 dispunha "A ninguém venderemos, negaremos ou retardaremos direito ou justiça". (Moura, 2000, p. 41).

160 DÓRIA, loc. cit.

161 Conforme transcrição de gravação em áudio da $4^{4}$ aula do Curso de Direito Processual Civil 
conceito de devido processo legal se identifica com aquilo que é fundamentalmente justo". ${ }^{162}$

Melhor razão assiste à segunda corrente. O devido processo legal biparte-se, hoje, em dois institutos: o devido processo legal adjetivo e o substantivo. O devido processo legal substantivo é um instituto que se aplica a todo direito, seja o direito substantivo, seja o processual. Interessa aqui examinar o devido processo legal adjetivo, princípio específico do Direito Processual. O devido processo legal adjetivo não é apenas o dever de seguir um processo previamente estabelecido na lei, pois, se o fosse, bastaria a expressão "processo legal", ou seja, processo devido a título da lei. A menção ao devido só pode indicar que o processo legal é devido não a título da lei, pois seria pleonasmo, mas a título de justiça. A existência do art. $40 \mathrm{da}$ Carta Magna, junto com o art. 39, não afasta essa interpretação, mas, pelo contrário, indica que essa concepção sempre esteve presente. O justo processo legal, ou seja, um processo legal que seja considerado justo, é aquele que obedece a uma série de princípios processuais. Lembra-se aqui a ordem crescente de densidade proposta por Canotilho: princípios estruturantes - princípios constitucionais gerais - princípios constitucionais especiais - regras constitucionais, todos dispostos no sistema em ordem piramidal, mas num processo bi-unívoco de esclarecimento reciproco. ${ }^{163} \mathrm{O}$ devido processo legal adjetivo seria, assim, um princípio constitucional geral que é concretizado por uma série de princípios constitucionais especiais (contraditório, ampla defesa, motivação, publicidade, imparcialidade etc.). Trata-se, portanto, de um princípio: existe, no sistema, um mandado de optimização da realização de um processo justo, na medida das possibilidades fáticas e jurídicas. Sendo um princípio, é normal que colida com outros princípios. E, diante do caso concreto, pode ter um peso diferenciado, sendo parcialmente ou, até mesmo, completamente afastado. Essa contribuição doutrinária explica porque o princípio do devido processo legal adjetivo tem aplicação diferenciada de acordo com o caso concreto. O princípio é sempre o mesmo, o peso do princípio é que muda de acordo com as circunstâncias.

\subsection{O devido processo legal e o processo administrativo}

Observa-se que muitos princípios que regem a função administrativa também estão abrangidos pelo princípio geral do devido processo legal, como, por exemplo, os princípios da motivação e da igualdade. Ambos fazem parte do conjunto de standarts que a humanidade atualmente exige para que um processo seja considerado justo. Ambos, no entanto, também regem a função administrativa em decorrência da indisponibilidade do interesse público. Conclui-se: esses princípios incidem no

ministrado pelo Min. Antonio Cezar Peluso na Pontifícia Universidade Católica de São Paulo, no ano de 1996.

162 O Devido Processo Legal na cultura jurídica dos Estados Unidos: passado, presente e futuro. Revista AJUFE, $\pi^{\circ}$ 56, ago./set./out., 1997, p. 33.

163 CANOTILHO, 2000, p. 1139. 
processo administrativo não em decorrência da incidência do devido processo legal, mas por se tratar de função administrativa.

Além dos princípios inerentes à função administrativa, incidem nos chamados processos administrativos de defesa, instaurados sempre que haja uma controvérsia envolvendo um direito (em sentido amplo) do administrado, os princípios do contraditório e da ampla defesa. Referidos princípios também fazem parte do conjunto de cânones que a humanidade exige para que um processo seja considerado justo. Incidem, no processo administrativo. não, porém. por força da incidência do devido processo legal, mas pela exigência expressa do art. $5^{\circ}$. LV da Constituição Federal. É por causa desse dispositivo que nos processos administrativos em que haja litigantes ou acusados em geral vigoram os princípios do contraditório e da ampla defesa. Esses princípios são concretizados por uma série de subprincípios: o direito ue audiência, o direito de acesso aos elementos do expediente, etc. ${ }^{16 t}$

Há, no entanto, princípios inerentes ao devido processo legal, necessários para a justiça do processo, tais como a imparcialidade e o juiz natural, que não regem a função administrativa nem são aplicáveis ao processo administrativo por determinação expressa da Constituição. Referidos princípios só serão aplicáveis ao processo administrativo se a este for aplicado o princípio geral do due process of lan'. Daí indagar-se se esse alicerce maior do processo jurisdicional aplicil-se ao processo administrativo.

A doutrina brasileira, sem exceções conhecidas, responde afirmativamente a questão. Ninguém questiona a incidência do devido processo legal no processo administrativo. ${ }^{165}$ A questão, contudo, por vários motivos, necessita ser revista. Três são os motivos que fundamentam a não aplicação do princípio do devido processo legal adjetivo no processo administrativo. O primeiro fundamento é normativo: o Constituinte de 1988 enunciou no inciso LIV do art. $5^{\circ}$ que "ninguém será privado da liberdade ou de seus bens sem o devido processo legal". No inciso seguinte prescreveu que "aos litigantes, em processo judicial ou administrativo. e aos acusados em geral são assegurados o contraditório e ampla defesa, com os meios e recursos a ela inerentes". Não determinou que o princípio do devido processo legal se aplique ao processo administrativo, mas tão-somente para privação da liberdade ou dos bens de alguém. Muitos fazem o seguinte raciocínio: o Constituinte determinou a incidência, no inciso LV, dos princípios do contraditório e da ampla defesa no processo administrativo e, como conseqüência disso, incide também o devido processo legal. $O$ raciocínio seria correto se fosse ao contrário: um processo justo exige necessariamente a incidencia do contraditório e da ampla defesa: num processo em que vigora o contraditório e a ampla defesa não se exige, necessariamente, todas as garantias

164 Em sentido contrário, Hely Lopes Meirelles entendia que o devido processo legal decorre do direito de defesa (1981, p. 663). Nada mais equivocado: a defesal é que necessíria para que o processo seja justo. Afirmar o direito de defesa não equivale a afirmar o devido processo legal. mas afirmar este equivale a afirmatr aquele.

65 Celso Antonio Bandeira de Mello, influenciado por Weida Zancaner. chega a colocar o principio entre os princípios constitucionais do direito administrativo brasileiro (2001, p. 85-89). 
eleitas pela humanidade para que um processo seja justo. Se o inciso LIV se aplicasse a todos os processos, não haveria necessidade do inciso LV: este seria inútil. raciocínio que viola regra elementar de hermenêutica. A análise dos incisos LIV e LV do art. $5^{\circ}$ da Lei Maior leva, portanto, a seguinte conclusão: a privação de bens ou da liberdade exige o devido processo legal. O processo administrativo não leva à privação de bens ou da liberdade. ao menos a privação definitiva, posto que sempre será passível de revisão judicial, e, assim, não há incidência necessária do due process of law. Há, tão-somente, a incidência dos princípios do contraditório e da ampla defesa em caso de acusação em geral ou litígio.

O segundo fundamento é de ordem lógica. No sistema do contencioso administrativo o justo processo da lei ocorre no âmbito da administração. Esta, no exercício de função jurisdicional. decide, definitivamente. os conflitos de interesses em que está envolvida. Nesse processo administrativo jurisdicional chegat-se a uma decisão final que não será passível de revisão pelo Judiciário. Percebe-se: daí a necessidade imperiosa de que todas as garantias exigidas pela humanidade para que um processo seja justo estejam presentes nesse processo administrativo jurisdicional. De administrativo esse processo só tem o nome e o órgão encarregado de presidi-lo. O juiz-administrador que atua nesse processo, ainça que funcionário da Administração, deve ser dotado de total imparcialidade. Sua competencia deve ser previamente fixada em lei. vigorando integralmente o princípio do juiz natural. Esse processo administrativo jurisdicional, enfatiza-se, não é passível de revisão pelo Judiciário, não haverá um outro justo processo para the corrigir os erros. No sistema inglês ou de jurisdição única, os processos não-jurisdicionais da Administração não levam a uma decisão definitiva, visto que essa decisão sempre poderá ser alterada pelo Judiciário caso atentatória ao ordenamento jurídico. Exigir um justo processo. com todas as garantias exigidas pela humanidade para que o processo seja justo é dar às decisões proferidas pela Administração dois justos processos. A Administração terá que instaurar um procedimento justo e. após. novo procedimento justo poderí ser instaurado perante o Poder Judiciário. Essa não é a lógcica do sistema, nunca a Ciência do Direito pretendeu fazer do sistema inglês um sistema de muito mais garantias do que o sistema francês. A Ciência do Direito exige que se dê ao cidadão a possibilidade de ver instaurado um processo justo para analisar seu conflito. No sistema francês, nos conflitos em que Administração esteja envolvida, esse processo justo se instaura na própria Administração: no sistema inglês. no Judiciário. Por un desvio, no entanto, intencional ou não intencionalmente gerado pelos doutrinadores, essa lógica foi quebrada: dá-se ao indivíduo, ao menos no ordenamento brasileiro, o direito de ver instaurado dois processos justos, um na Administração e outro no Judiciário. Indaga-se. então, se o processo administrativo já foi justo, em que todas as garantias exigidas pela humanidade para que se cheque a uma justa decisão foram obedecidas, por que se faz necessária a possibilidade de instauração de um novo processo no Judiciário. Pela razão óbvia: o processo administrativo não reúne, e nem deve reunir, os predicados exigidos para ser justo, pois nele não atuam todos os predicados do princípio do devido processo legal. 
O terceiro fundamento é de ordem prática. A Administração não pode retirar a liberdade e os bens das pessoas através do processo administrativo. Essa regra é pacificamente aceita pela doutrina. Assim, pode cobrar uma multa ou um tributu. mas, se o devedor não pagar, não poderá executar seu patrimônio: deverá valer-se da execução fiscal, processo jurisdicional. Pode embargar uma obra, mas para demoli-la é pacífico que não pode fazê-lo através do processo administrativo: a demolição só poderá ser obtida através de ação demolitória. Essa orientação doutrinária e jurisprudencial pacífica leva a perguntar-se por que a Administração não poderia através do processo administrativo executar os bens do devedor. Se o devedor vislumbrasse algum vício, alguma ilegalidade, poderia recorrer ao Judiciário. A resposta ao problema prático é evidente: para privação da liberdade ou da propriedade dos bens do indivíduo necessária, por imposição constitucional, a instiuração de um processo em que se assegure o devido processo legal e este só é assegurado no processo jurisdicional. Por força disso, para executar o patrimônio de alguém a Administração tem que necessariamente propor uma ação judicial, para efetivar a cobrança de um tributo ou de uma multa tem que necessariamente propor uma execução fiscal. Se o processo administrativo observasse o devido processo legal essas exigências seriam despropositadas.

Fundamentos de ordem normativa, lógica e prática justificam a não incidência do princípio do devido processo legal no processo administrativo. Conseqüentemente, todos os princípios que não regem a função administrativa e que não são expressamente exigidos pelo texto constitucionais, não se aplicam ao processo administrativo. No processo administrativo vigoram us princípios da legaliclade, impessoalidade, moralidade, publicidade, eficiência, motivação. lealdade, boa fé, razoabilidade, proporcionalidade, finalidade em decorrência dos princípios gerais da supremacia do interesse público sobre o privado e da indisponibilidade do interesse público, estruturas mestras do Direito Administrativo. Aos processos administrativos de defesa aplicam-se os princípios do contraditório e dá ampla defesa por imposição expressa do texto constitucional. Outros princípios constantes da cláusula do devido processo legal, não decorrentes do exercício da função administrativa, nem de imposição expressa do constituinte, não se aplicam em face da não aplicação do próprio due process of law. Assim, apenas para exemplificar, não há que se falar, no ordenamento jurídico brasileiro, do princípio do administrador natural, ${ }^{166}$ nem do princípio da imparcialidade.

Nada impede, todavia, que o legislador institua maiores garantias ao administrado do que as exigidas pelo sistema constitucional. Foi o que fez o legislador federal na lei de processo administrativo, ao prever os institutos do impedimento e da suspeição (Lei Federal, arts. 18-21): tentou implementar o princípio da imparcialidade no processo administrativo (de defesa). Não há inconstitucionalidade nesses dispositivos desde que se efetue, no caso concreto, a devida ponderação entre o

166 As próprias leis do processo administrativo autorizam a avocação e a delegação de competências (arts. 11 a 17 da Lei Federal 9.784/99 e 19 e 20 da Lei Paulista 10.177/98). 
princípio do interesse público e os direitos dos administrados. O processo administrativo de defesa tem dois fins, como já afirmado: é uma garantia aos administrados e é um meio de exercício da função administrativa. Esses fins devem ser perseguidos de forma equilibrada, pois a ênfase desmedida nas garantias pode impossibilitar o exercício da função administrativa e impedir a satisfação do interesse público.

Registra-se, por fim, que os princípios do contraditório e da ampla defesa não atuam no processo administrativo de defesa da mesma forma que atuam no processo jurisdicional. O fim último do processo jurisdicional é a obtenção da justa solução do litígio. No processo administrativo de defesa, como dito, dois são os fins: possibilitar o cumprimento da função administrativa e garantir os direitos dos administrados. A exigência de equilíbrio entre esses dois desideratos, inexistente no processo jurisdicional, faz, por óbvio, que os princípios do contraditório e da ampla defesa atuem de forma diferenciada. Muitos ônus e direitos por eles gerados no processo jurisdicional, não encontram correspondência no processo administrativo. No processo penal, por exemplo, o réu não pode ser processado sem estar assistido por um advogado: no processo administrativo disciplinar, conforme decidido pelo Supremo Tribunal Federal, a presença de advogado é dispensável (MS 22921/SP, Rel. Min. Carlos Velloso, julgado em 05.06.02).

\section{Conclusões}

1. O Direito Processual foi o ramo do Direito em que mais se discutiu sobre a natureza jurídica do processo e, por isso, as contribuições dos processualistas foram tomadas como ponto de partida para a fixação de seu conceito. Afastou-se, de imediato, a teoria contratual do processo. incompatível com o monopólio do poder pelo Estado, bem como a teoria do quase-contrato, incompatível com a desvinculação do processo do direito privado. Afastaram-se também as teorias da entidade jurídica complexa e da instituição por serem pouco esclarecedoras. A teoria da relação jurídica processual, nos termos em que foi proposta por Oskar von Bülow. também se mostrou insustentável. Nos termos da crítica formulada por James Goldschmidt, o processo jamais poderia ser tomado como uma relação similar à relação obrigacional. A teoria da situação jurídica também foi afastada em face dos avanços da Teoria Geral do Direito.

2. Após, examinou-se a posição daqueles que tomam o processo como sinônimo de procedimento. Referida teoria foi repudiada por imposição dogmática: em face da redação do art. 24 , XI, da Constituição da República. Após, examinou-se a teoria do procedimento contraditório que, corretamente entendida, é equivalente à nova formulação da teoria da relação jurídica processual. As duas consistem em dois enfoques da mesma realidade. Contraditório aí, conforme examinado, não possui significado técnico, podendo ser tomado como sinônimo de participação. Processo passa a ser considerado um mecanismo democrático de tomada de decisões, ou seja, de exercício do poder, apóia-se sobre uma idéia básica: o exercício do poder só é legítimo se possibilitar a participação dos interessados. 
3. A partir das consideraçōes de Pietro Perlinģieri, relação jurídica deixou de ser considerada sinônimo de obrigação. passa a ser relaçẫo entre situações jurídicas. nexo que liga dois ou mais sujeitos, atribuindo-lhes poderes, direitos, faculdades e os correspondentes deveres, obrigações, sujeições, ônus. Com essa reformulação do conceito de relação jurídica. caiu por terra a crítica de James Goldschmidt. O processo passa a ser visto como uma complexa relação jurídica entre autor, réu e Estado-juiz, em que, referentemente a cada um desses sujeitos. há inúmeras situaçoes jurídicas complexas: poderes, faculdades, deveres, sujeiçôes. ônus. Concluiu-se que essa relação é pública, autônoma, progressiva, dotada de unidade e de estrutura angular.

4. Processo, então, foi tomado como uma forma de exercício da democracia que tem por finalidade garantir aos interessados o direito de participar do exercício do poder, ou seja, da tomada de decisão por um agente estatal. E composto de dois elementos estruturais, intrinsecamente ligados em prol dessa finalidade: uma seqüência de atos normativamente encadeados, em que cilda ato é conseqüente do posterior e decorrente do anterior (procedimento) e uma relação jurídica entre os interessados e o Poder Público, representado pelo agente encarregado de proferir a decisão. relação complexa abrangente de todas as situações que surjam durante o procedimento. A matéria processual compõe-se. portanto. da disciplina da relação jurídica e do procedimento. Por imposição dogmática, separaram-se os assuntos diretamente ligados à disciplina do procedimento dos assuntos diretamente ligados à disciplina da relação jurídica, dando-se sentido às disposições constitucionais. Estas não impedem que entre processo e procedimento vislumbre-se uma relação de inclusão. desde que, a partir de uma interpretação sistemática tome-se o inciso XI do art. 24 da Lei Maior como uma restrição ao inciso I de seu art. 22. Manteve-se, assim, plena afinidade entre as recentes concepções doutrinárias e o ordenamento jurídico brasileiro, denominando-se o conceito obtido, por força das sólidaıs premissas que o sustentam, de conceito científico do processo.

5. Passou-se, então, a analisar o tema no âmbito do Direito Administrativo. Inicialmente o instituto era tratado na teoria dos atos administrativos. Procedimento administrativo, nessa teoria, é o conjunto dos requisitos procedimentais do ato administrativo conclusivo e cadia ato do procedimento é um requisito procedimental do ato posterior. A partir das considerações de Merkel. no entanto, adotou-se a regra de que nenhuma decisão estatal deveria ser tomada fora de um procedimento, sob pena dessa decisĩo traduzir-se na imposição autoritária da vontade do agente que a emite. O procedimento passou, então, a ser responsável pela legitimidade do exercício da função administrativia.

6. Apurou-se a preferência da doutrina no período anterior à Constituição de 1988 pela expressão "procedimento administrativo" e uma certa repulsa à expressão "processo administrativo". Após a promulgação dat Constituição, a situação, no Brasil, inverte-se em face da utilização da expressào "processo administrativo" em vários dispositivos constitucionais. Um panorama da doutrinat brasileira. todavia. revelou absoluta falta de uniformidade na utilização das expressões processo e procedimento administrativos. Todas as doutrinas expostas, sem exceção, afastaram- 
se, em maior ou menor medida, do conceito científico de processo anteriormente fixado.

7. Concluiu-se que os conceitos de procedimento e processo, desenvolvidos a partir das formulações enunciadas no primeiro capítulo, são inteiramente aplicáveis ao Direito Administrativo. Procedimento administrativo é uma série de atos administrativos autônomos, ordenados de modo que cada ato seja condição de validade do ato anterior, teleologicamente vinculados para a expedição do ato administrativo conclusivo, consistente numa decisão da Administração. Processo Administrativo consiste num procedimento administrativo em que vigore uma relação jurídica entre a Administração e os interessados diretos na tomada de decisão. Nessa relação jurídica há uma série de situações jurídicas instituídats em favor desses administrados, garantido-lhes a possibilidade de influenciar na tomada de decisão. A adoção dos termos processo e procedimento administrativo impõe-se por dois motivos: pelos critérios normativo e científico.

8. Verificou-se que o processo administrativo prende-se a dois fins: de um lado. é o meio de exercício da função administrativa, visando possibilitar, da melhor forma possível, o exercício da função administrativa, ou seja, que ela cumpra, da melhor maneira, os seus deveres; de outro, é o meio pelo qual o cidadão influi na atividade administrativa, sendo, nesse sentido, um direito político do cidadão. Esses dois fïns traduzem-se em dois princípios: o principio democrático e o princípio da efïciência.

9. Vislumbrou-se duas espécies de processo administrativo, tendo em vista sua finalidade. Nos processos administrativos em que há uma controvérsia sobre um direito (em sentido amplo) do administrado, qualquer que seja ela, incidem os princípios do contraditório e da ampla defesa, daí a denominação: processos administrativos de defesa. Nesses, o acusado ou litigante tem o direito de participação, de influir na decisão fïnal, mas, esse direito político é acrescido de um plus: trata-se de uma garantia constitucional individual que dá ao administrado um leque muito maior de situações jurídicas, próprias do princípio do contraditório. Nos casos em que não há controvérsia sobre um direito (em sentido amplo) do administrado, a Administração não tem que instaurar um processo administrativo de defesa e observar o princípio do contraditório. Mas, para tomar uma decisão, nesses casos, tem que instaurar um processo pelo qual uma série de situações jurídicas seja instituída em favor dos cidadãos, permitindo-lhes influenciar na decisão a ser tomada, daí a denominação: processos administrativos de participação. Esse dever só é afastado se, no caso concreto, diante das circunstânciass, o princípio do interesse público (defesa da saúde ou segurança da população, por exemplo) apresentar maior peso que o princípio democrático.

10. Procedimentos administrativos autônomos, conforme se apurou, configuram-se quando, apesar de existir procedimento em sentido técnico, não há que se falar em relação jurídica processual, pois só agentes da própria Administração atuam no expediente. A relação entre os agentes e a Administração é uma relação de direito material decorrente do vínculo estatutário que nada tem a ver com o expediente em si, não sendo, por isso, processual. Os procedimentos administrativos autônomos surgem sempre que a Administração precisa praticar um ato material e para tanto é necessária a prática de mais de um ato administrativo. Surge também nos raros casos 
em que a Administração precisa tomar uma decisão. mas, por força de circunstâncias peculiares do caso concreto. o princípio democrático. que exige a realização do processo de participação, é afastado pelo princípio do interesse público.

11. Esclareceu-se que legislar sobre direito administrativo é decorrência lógica da autonomia política do ente federativo, expressamente prevista no art. 18 da Constituição. Sempre que o constituinte quis excepcionar essa regra o fez expressamente. Não havendo referência expressa nos incisos I do art. 22 e XI do art. 24 ao Direito Administrativo a regra geral permanece incólume: esses dispositivos só se aplicam à função jurisdicional. Daí a conclusão: legislar sobre o processo e procedimento administrativos de cada entidade federativa compete à respectiva entidade.

12. A análise dos institutos fundamentais do Direito Processual jurisdicional revelou acentuadas diferenças entre as duas formats de exercício do poder estatal. Todos os institutos fundamentais do Direito Processual (jurisdicional), jurisdição, ação, defesa e processo, encontram correspondência no Direito Processual Administrativo, nem todos, porém. a título fundamental. O direito de petição, correspondente ao direito de ação, não é categoria indispensável para instauração do processo em face da não aplicação dos princípios da inércia da jurisdição e da demanda e, assim, não é instituto fundamental. O direito de defesa só surge em certos tipos de processos administrativos, não se configurando nos processos de participação.

13. Diferenças importantes foram registradas: o processo jurisdicional produz decisões definitivas (coisa julgada). ao contrário das decisões do processo administrativo, sempre passíveis de revisão pelo Judiciário: no processo jurisdicional o juiz não faz parte da lide, no processo administrativo al Administração sempre é parte. Por fim. no processo jurisdicional. ao contrário do administrativo. aplica-se o princípio do devido processo legall.

14. O devido processo legal adjetivo é um princípio constitucional geral concretizado por uma série de princípios constitucionais especiais (contraditório, ampla defesa, motivação, publicidade, imparcialidade etc.), cuja observância é necessária para que o processo legal seja considerado justo. Fundamentos de ordem normativa, lógica e prática justificaram a não incidência do princípio do devido processo legal no processo administrativo. Concluiu-se que no processo administrativo vigoram os princípios da legalidade, impessoalidade, moralidade, publicidade, eficiência, motivação, lealdade, boa fé. razoabilidade, proporcionalidade, finalidade, todos em decorrência dos princípios gerais da supremacia do interesse público sobre o privado e da indisponibilidade do interesse público, estruturas mestras do Direito Administrativo. Aos processos administrativos de defesa aplicam-se os princípios do contraditório e da ampla defesa por imposição expressa do texto constitucional (art. $5^{\circ}$, LV). Outros princípios constantes da cláusula do devido processo legal, não decorrentes do exercício da função administrativa, nem de imposição expressa do constituinte, não se aplicam em face da não aplicação do próprio due process of law.

15. Finalmente, registrou-se que os princípios do contraditório e da ampla defesa não atuam no processo administrativo de defesa da mesma forma que atuam no processo jurisdicional. No processo administrativo de defesa, como dito, dois são os fins: possibilitar o cumprimento da função administrativa e garantir os direitos dos 
administrados. A exigência de equilíbrio entre esses dois desideratos, inexistente no processo jurisdicional, faz, por óbvio. que os princípios do contraditório e da ampla defesa atuem de forma diferenciada.

Referências Bibliográficas

ALEXY, Robert. Teoria de los Derechos Fundamentales. Tradução de Ernesto Garzón Valdés. 1. ed.. 2. reimpr. Madri: Centro de Estudios Políticos Y Constitucionales, 2002. Título original: Theorie Der Grundrechte.

- Princípios Jurídicos y Razón Práctica. In Derecho y Razón Práctica. 2. reimpr. corrig. México: Fontamara, 2002.

ALVES, Alaôr Caffé. Lógica: pensamento formal e argumentação. 2. ed. São Paulo: Quartier Latin, 2002.

ÁVILA, Humberto. Teoria dos Princípios: da definição à aplicação dos princípios jurídicos. São Paulo: Malheiros, 2003.

BANDEIRA DE MELLO, Celso Antonio. Curso de Direito Administrativo. 13. ed. rev., atual e ampl. São Paulo: Malheiros, 2001.

BANDEIRA DE MELLO. Oswaldo Aranha. Principios Gerais de Direito Administrativo. Rio de Janeiro: Forense, 1968, v. I.

BÜlOW, Oscar Von. Teoria das Exceçoes e dos Pressupostos Processuais. Tradução e notas de Ricardo Rodrigues Gama. Campinas: LZN, 2003.

CAETANO, Marcelo. Manual de Direito Administrativo. 10. ed., 6. reimpr. Coimbra: Almedina, 1999.

CANOTILHO, J. J. Gomes. Direito Constitucional e Teoria da Constituição. 4. ed. Coimbra: Almedina, 2000.

CARRIÓ, Genaro R. Notas sobre derecho y lenguaje. 4. ed. correg. y aum, reimpr. Buenos Aires: Abeledo-Perrot, 1994.

CARVAlHO, Paulo de Barros. Curso de Direito Tributário.14. ed., rev. e atual. São Paulo: Saraiva, 2002.

CINTRA, Antonio Carlos de Araujo: GRINOVER. Ada Pellegrini; DINAMARCO, Cândido Rangel. Teoria Geral do Processo. 11 ed. São Paulo: Malheiros, 1995.

COLE, Charles D. O Devido Processo Legal na cultura jurídica dos Estados Unidos: passado, presente e futuro. Revista AJUFE, n. 56, ago./set./out. 1997, p. 33-43.

COUTURE. Eduardo J. Fundamentos del Derecho Procesal Civil. 4ta. ed. Montevideo: IBef, 2002.

DINAMARCO. Cândido Rangel. A Instrumentalidade do processo. 10 ed. rev. e atual. São Paulo: Malheiros, 2002.

Os institutos fundamentais do Direito Processual. In Fundamentos do Processo Civil Moderno. 4. ed. São Paulo: Malheiros, 2001, Tomo I. Princípio do Contraditório e sua Dupla Destinação. In: Fundamentos do

Processo Civil Moderno. 4. ed.. São Paulo: Malheiros. 2001, Tomo I. Execuçāo Civil. 6. ed. rev. e atual. São Paulo: Malheiros. 1998. 
DI PIETRO, Maria Sylvia Zanella. Direito Administrativo. 11. ed. São Paulo: Atlas, 1999.

DÓRIA. Antonio Roberto Sampaio. Direito Constitucional Tributário e Due Process of Law. Rio de Janeiro: Forense. 1964.

DWORKI, Ronald. Le'ando os Direitos à Sério. 1. ed. São Paulo: Martins Fontes, 2002. Título original: Taking Rights Seriously:

ENTERRÍA, García de: FERNÁNDEZ. Tomás-Ramón. Curso de Drecho Administrativo. 8. ed. Madri: Civitas, 2002, v. II.

FERRAZ. Sérgio: DALLARI, Adilson Abreu. Processo Administrativo. Sũo Puulo: Malheiros, 2001.

FIGUEIREDO, Lúcia Valle. Curso de Direito Administrativo. 6. ed rev.. atual. e ampl. São Paulo: Malheiros, 2003.

GASPARINI, Diógenes. Direito Administrativo. 9. ed. rev. e atual. São Paulo: Saraiva. 2004.

GOLDSCHMIDT. James. Dircito Processual Civil. Tradução de Lisa Pary Scarpa. 1. ed. Campinas: Bookseller. 2003.

GOMES, Orlando. Obrigações. 10. ed. Rio de Janeiro: Forense. 1995.

GORDILLO. Augustín. Tratado de Derecho Administrativo: la defensa del usuario $y$ del administrado. 1. ed. colombiana. Bogotá: Fundación de Derecho Administrativo, Bibliotecal Jurídica Dike. 1998.

HAURIOU, Maurice. La Teoria de la Institucion y de la Fundación: ensayo de vitalismo social. Tradução do francês, prólogo e bibliografia do autor por Arturo Enrique Sampay. Buenos Aires: Abeledo-Perrot, 1968.

HOUAISS, Antônio; VILLAR, Mauro de Salles. FRANCO, Francisco Manoel de Mello (Editores). Dicionario Houaiss da Lingua Portuguesa. Elaborado no Instituto Antônio Houaiss de Lexicografia. Rio de Janciro: Objetiva, 2001.

LUHMAN, Nicklas. Legitimaşão pelo procedimento. Tradução de Maria da Conceição Corte-Real. Brasília: Editora Universidade de Brasília. 1980.

MALACHINI, Edson Ribas. A Constituição Fuderal e a legislação concorrente dos Estados e do Distrito Federal em matéria de procedimentos. Revista Forense, Rio de Janeiro, v. 89. n. 324, out./dez. de 1993, p. 49-54.

MARINONI, Luiz Guilherme; ARENHART, Sérgio Cruz. Manual do Processo de Conhecimento: a tutela jurisdicional através do processo de conhecimento. São Paulo: Revista dos Tribunais, 2001.

MANCUSO, Rodolfo de Camargo. Interesses Difitsos: conceito e legitimação para agir. 5. ed. ver. e atual. São Paulo: Revista dos Tribunais, 2001.

MARQUES, José Frederico. Elementos de Direito Processual Penal. Campinhas: Bookseller, 1997, v. I.

MEIRELLES, Hely Lopes. Direito Administrativo Brasileiro. 8. ed. atual. São Paulo: Revista dos Tribunais, 1981.

MONTEIRO DE BARROS, Flávio Augusto. Direito Penal: parte geral. 2, ed. rev., atual. e ampl. São Paulo: Saraiva, 2001.

MOREIRA NETO, Diogo Figueiredo Moreira. Curso de Direito Administrativo. 13. ed. rev., ampl. e atual. Rio de Janeiro: Forense. 2003. 
MOURA, Elizabeth Maria de. O Devido Processo Legal na Constituição Brasileira de 1988 e o Estado Democrático de Direito. São Paulo: Celso Bastos Editor, 2000.

OLIVEIRA, Gustavo Henrique Justino de Oliveira. As Audiências Públicas e o Processo Administrativo Brasileiro. Revista Trimestral de Direito Público. São Paulo, n. 21, 1998. p. 161-172.

PALOP, Vicente Escuin. El acto administrativo implícito. 1. ed. Madri: Civitas, 1999.

PEREZ, Marcos Augusto. Participação popular na Administração Plíblica. Revista Trimestral de Direito Público. São Paulo, n. 31, 2000.

PERLINGIERI, Pietro. Perfis do Direito Civil: introdução ao Direito Civil Constitucional. Tradução de Maria Cristina De Cicco. 2. ed. Rio de Janeiro: Renovar, 2002.

PORTA, Marcos. Processo administrativo e o devido processo legal. São Paulo: Quartier Latin, 2003.

SARMENTO, Daniel. A Ponderação de Interesses na Constituição Federal. $1^{a}$ ed., $2^{\mathrm{a}}$ tir., Rio de Janeiro: Lumen Juris, 2002.

SIMÕES. Mônica Martins Toscano. O processo administrativo e a invalidação dos atos viciados. São Paulo: Malheiros. No prelo.

STEINMETZ, Wilson Antônio. Colisão de Direitos Fundamentais e Princípio da Proporcionalidade. Porto Alegre: Livraria do Advogado, 2001.

SUNDFELD, Carlos Ari. Competência Legislativa em Matéria de Processo e Procedimento. Revista dos Tribunais, São Paulo, v. 79, n. 657, jul. de 1990, p. 32-36. . A importancia do procedimento administrativo. Revista de Direito Público. São Paulo, n. 84, Ano XX, out.-dez. de 1987, p. 64-74.

. Processo e procedimento administrativo no Brasil. In SUNDFELD. Carlos Ari (coord.); MUÑOZ, Guillermo Andrés (coord.). As Leis de Processo Administrativo: Lei Federal 9.784/99 e Lei Paulista 10.177/98. São Paulo: Malheiros, 2000, p. 17-36. 